\title{
Effect of Irrigation Systems and Water Regime on Growth, Yield Components, Water Use Efficiency and Water Productivity of Guava (PSIDIUM GUAVAJA L.) Grown in Clay Soil
}

\author{
Ashraf E. Elnamas
}

\begin{abstract}
Field experiments were conducted during two successive growing seasons ( 2017/2018 and 2018/2019) in Guava orchard at Kafr Al Dawar district, Beheira Governorate, Egypt, to investigate the effect of water regime levels: $100 \%\left(E_{1}\right), 80 \%\left(E_{2}\right)$ and $60 \%\left(E_{3}\right)$ of crop evapotranspiration $\left(\mathbf{E T}_{\mathbf{c}}\right)$ under two irrigation systems: furrow irrigation $\left(I_{1}\right)$ and surface drip irrigation $\left(I_{2}\right)$ on water use efficiency, growth parameters, yield components, and economic analysis of four years old guava trees grown in clay soil. The field experiments were implemented in a randomized complete block design with three replicates. The obtained results indicated that the highest shoot length, number of leaves/m and leaf area were obtained due to $T_{2} E_{1}$ treatment (drip irrigation with $100 \% \mathbf{E T}_{\mathrm{c}}$ ), followed by $\mathrm{I}_{2} \mathrm{E}_{2}$ treatment (drip irrigation with $80 \% \mathbf{E T}_{\mathrm{c}}$ ). The average highest guava yield of the two growing seasons was 26.64 tons/ha which was obtained as a result of $I_{2} E_{1}$ treatment (drip irrigation with $100 \%$ of

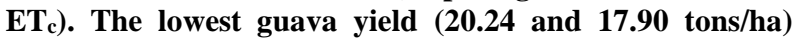
were obtained due to $I_{1} E_{3}$ treatment (furrow irrigation with $60 \%$ of $E T_{c}$ ) for the two growing seasons, respectively. Yield components such as number of fruits $/ \mathrm{m}$, length of fruit $(\mathrm{cm})$, diameter of fruit $(\mathrm{cm})$, fruit size $\left(\mathrm{cm}^{3}\right)$ , fruit weight (gm.) and yield (kg/tree) were significantly effected $(\mathrm{P}<0.05)$ by water regime levels and irrigation systems. Water use efficiency (WUE) of drip-irrigated treatments was higher than that obtained from furrow irrigated treatments in the two growing seasons. WUE increased from 2.37 to $3.34 \mathrm{~kg} \cdot \mathrm{m}^{-3}$ for drip - irrigated treatment, and from 1.63 to $2.18 \mathrm{~kg}^{-\mathrm{m}^{-3}}$ for furrow irrigated treatments. Fruit quality such as TSS (\%), acidity (\%) and TSS / Acidity ratio were not significantly affected by irrigation systems and water regime. For the economical results, the maximum value of net return was due to $I_{2} E_{1}(24411 \mathrm{LE} /$ fed $)$ treatment for the two growing seasons and the minimum value of total return was the result of $\mathrm{T}_{1} \mathrm{E}_{3}(6344 \mathrm{LE} / \mathrm{fed})$ treatment for the two growing seasons. The maximum values of water productivity were obtained under $T_{2} E_{1}\left(5.56 \mathrm{LE} / \mathrm{m}^{3}\right)$ and $\mathbf{I}_{2} E_{2}\left(5.25 \mathrm{LE} / \mathrm{m}^{3}\right)$ treatments in the two growing seasons.
\end{abstract}

Key Words: Guava, Clay soil, Drip irrigation, Furrow irrigation, Yield component, Water use efficiency, Water productivity.

\section{INTRODUCTION}

Guava (PSIDIUM GUAVAJA L.) is one of the major fruits in Egypt and is ranked the eighth most important fruit as per area and production. The fruit is a rich source of vitamin $\mathrm{C}$, pectin and minerals like calcium, phosphorus and iron. The total area planted with guava is about 16,531 hectares. This area is divided into 12,838 hectares in old areas that are irrigated by surface irrigation methods, while 3,692 hectares in new lands that are irrigated by modern irrigation methods.

Egypt is seeking to increase the new reclaimed lands, but limited water resources constrain ambitious expansion plans (Abdel Mowgowd et al., 2010 and Darwish et al., 2013). Therefore, Egypt initiated a strategic program aiming to reclaim 1.4 million hectares of desert during the coming years till 2020 (Abdel Mowgowd et al., 2010). Climate change has forced decision makers and scientists to think about the future of water resources (Bisbis et al., 2018 ) and their sustainability in a scarcity situation, taking into account less water coming from Ethiopia to Egypt and a high rate of population growth (Ouda, 2016). So that, Badr et al., (2010) and Saleh et al., (2012) recommend the use of modern irrigation systems, instead of traditional surface irrigation such as furrow irrigation. Efficient water delivery systems can contribute towards increased crop yield and improving crop water use efficiency (Badr et al., 2010). Improving WUE may help to minimize water consumption, reduce losses of irrigation water, and increase cultivated area.

Currently in Egypt, the country's tendency to convert surface irrigation systems into modern irrigation systems due to a $30 \%$ decrease in the efficiency of surface irrigation on modern irrigation methods due to the loss of seepage and evaporation, as well as increasing the amount of water added during irrigation and deep percolation (Singh, 2005).

Drip irrigation has arguably become the world's most valued innovation in agriculture irrigation since the invention of the impact sprinkler, which replaced flood irrigation. It proves efficiently in providing irrigation water and nutrients to the roots of plants, while maintaining high yield production. Furrow irrigation is the conventional method widely used to irrigate most of the fruit crops grown in old areas, Egypt. However, this method uses more water

\footnotetext{
DOI: $10.21608 / A S E J A I Q J S A E .2020 .101396$

1 Department of Soil and Water Science, Faculty of Agric., Alexandria University

Received May 20, 2020, Accepted, , June 29, 2020.
} 
compared to other high-tech water-saving irrigation methods such as sprinkler, drip etc.... Many researchers have reported higher application efficiency of drip irrigation systems over the conventional basin irrigation systems (Salvin et al., 2000; Bharambe et al., 2001; Agrawal and Agrawal, 2007) as compared to drip and furrow irrigation systems in fruits since they found that there was savings of 40 to $60 \%$ more irrigation water than another surface irrigation methods.

Guava is often marketed as "super-fruit" which has a considerable nutritional importance in terms of vitamins $\mathrm{A}$ and $\mathrm{C}$ with seeds that are rich in omega-3, omega- 6 polyunsaturated fatty acids and especially dietary fiber, riboflavin, as well as proteins, and mineral salts. The high content of vitamin $\mathrm{C}$ (ascorbic acid) in guava makes it a powerhouse in combating free radicals and oxidation that are key enemies that cause many degenerative diseases. The high content of vitamin A in guava plays an important role in maintaining the quality and health of eyesight, skin, teeth, bones and the mucus membranes (Singh and Singh, 2007). Patil and Patil (1999) revealed that guava fruit yield was high at maximum when irrigated at $80 \%$ of the potential evapotranspiration. Singh and Singh (2007) observed that there was $164 \%$ greater yield in case of drip as compared to furrow irrigation in guava.

The aim of this research was to evaluate the effect of deficit irrigation treatments and irrigation systems on the vegetative growth, yield and yield components, applied irrigation water, water use efficiency and economic return analysis of guava plants grown in clay soil.

\section{MATERIALS AND METHODS}

Field experiments were carried out in a private orchard at Kafr Al Dawwar district, Beheira Governorate, Egypt $\left(31^{\circ} 13^{\prime} \mathrm{N}, 30^{\circ} 25^{\prime} \mathrm{E}\right)$ during two growing successive seasons : 2017 / 2018 and 2018 / 2019 to study the effects of irrigation systems and water regime on the growth performance of guava ( Psidium Guavaja L. ) grown in clay soil . The meteorological data of the experimental site are given in Table 1.

Table 1. The meteorological ${ }^{*}$ data of the experimental site during the two growing seasons 2017 /2018 and 2018 / 2019

\begin{tabular}{cccccccc}
\hline \multirow{2}{*}{ Months } & \multicolumn{3}{c}{ Temperature $\left(\mathbf{c}^{\mathbf{0}}\right)$} & $\begin{array}{c}\text { Relative } \\
\text { humidity }(\boldsymbol{\%})\end{array}$ & $\begin{array}{c}\text { Precipitatin } \\
(\mathbf{m m})\end{array}$ & $\begin{array}{c}\text { Wind } \\
\text { speed(m/hr) }\end{array}$ & $\begin{array}{c}\text { Sun shine } \\
(\mathbf{h r} .)\end{array}$ \\
\cline { 2 - 4 } Maximum & Minimum & Mean & \multicolumn{2}{c}{$2017 / 2018$} & & & \\
Jan. & 18.2 & 12.6 & 15.4 & 69.1 & 33.9 & 5.4 & 9.3 \\
Feb. & 20.1 & 12.8 & 16.5 & 69.1 & 12.1 & 4.3 & 10.5 \\
Mar. & 23.7 & 14.2 & 19.0 & 59.6 & 1.5 & 5.2 & 11.3 \\
Apr. & 25.6 & 16.2 & 20.9 & 59.7 & 2.8 & 4.5 & 12.1 \\
May & 28.9 & 20.0 & 24.5 & 60.9 & 0.0 & 4.4 & 12.8 \\
June & 31.0 & 22.5 & 26.3 & 58.2 & 0.0 & 4.3 & 13.2 \\
July & 32.2 & 24.2 & 28.2 & 63.5 & 1.7 & 4.7 & 13.3 \\
Aug. & 32.1 & 25.0 & 28.6 & 64.5 & 0.0 & 4.5 & 12.8 \\
Sep. & 31.2 & 24.0 & 27.6 & 63.6 & 0.0 & 4.8 & 12.1 \\
Oct. & 28.1 & 21.7 & 24.9 & 63.6 & 11.1 & 4.6 & 10.9 \\
Nov. & 24.2 & 18.3 & 21.3 & 64.4 & 23.4 & 4.1 & 9.7 \\
Dec. & 19.5 & 14.8 & 17.2 & 68.5 & 51.0 & 5.3 & 9.2 \\
\hline & & & & $2018 / 2019$ & & & \\
Jan. & 17.3 & 10.4 & 13.9 & 64.1 & 25.2 & 5.9 & 9.6 \\
Feb. & 18.3 & 11.1 & 14.7 & 67.2 & 14.3 & 4.9 & 10.4 \\
Mar. & 19.8 & 12.5 & 16.2 & 66.5 & 25.3 & 5.1 & 11.1 \\
Apr. & 22.8 & 14.2 & 18.5 & 62.0 & 3.5 & 4.8 & 12.2 \\
May & 29.1 & 18.4 & 23.8 & 53.9 & 0.0 & 4.6 & 12.6 \\
June & 30.9 & 22.8 & 26.9 & 63.1 & 0.0 & 4.6 & 13.4 \\
July & 32.4 & 24.5 & 28.5 & 61.1 & 0.0 & 4.7 & 13.5 \\
Aug. & 32.7 & 24.6 & 28.7 & 63.3 & 0.0 & 4.4 & 13.0 \\
Sep. & 30.4 & 23.4 & 26.9 & 63.7 & 0.0 & 4.6 & 12.2 \\
Oct. & 28.8 & 21.9 & 25.4 & 65.8 & 17.9 & 4.4 & 10.7 \\
Nov. & 26.3 & 18.9 & 22.6 & 63.1 & 0.2 & 4.3 & 9.5 \\
Dec. & 20.4 & 14.9 & 17.8 & 67.7 & 40.2 & 5.6 & 9.3 \\
\hline
\end{tabular}

*From the following website: https://power.larc.nasa.gov/ data-access-viewer. 
Four years old guava trees were grown at $4.0 \times 4.0$ m. apart in clay soil. The fertilizers dose of $100 \%$ which included, $138 \mathrm{~g} \mathrm{~N}, 244 \mathrm{~g} \mathrm{P}$ and $360 \mathrm{~g} \mathrm{~K}$ was applied to each tree of the recommended dose as suggested by Ministry of Agriculture and Land Reclamation (MALR) was followed.

\section{Experimental Layout:}

Two irrigation methods and irrigation water regime was applied during two successive growing seasons; 2017/2018 and 2018/2019. Two irrigation methods were furrow irrigation (FI) and surface drip irrigation (SDI) and three irrigation water regime (100, 80 and 60 $\%$ of crop evapotranspiration $\left(\mathrm{ET}_{\mathrm{c}}\right)$ from class A pan evaporation (FAO, 1998).

The overall treatments were:

\begin{tabular}{lll} 
i. & $\mathrm{I}_{1} \mathrm{E}_{1}$ & $\begin{array}{l}\text { Furrow irrigation }+100 \% \text { of } \\
\text { (Control) }\end{array}$ \\
ii. & $\mathrm{ET}_{1} \mathrm{E}_{2}$ & Furrow irrigation $+80 \%$ of $\mathrm{ET}_{\mathrm{c}}$ \\
iii. & $\mathrm{I}_{1} \mathrm{E}_{3}$ & Furrow irrigation $+60 \%$ of $\mathrm{ET}_{\mathrm{c}}$ \\
iv. & $\mathrm{I}_{2} \mathrm{E}_{1}$ & Surface drip irrigation $+100 \%$ of $\mathrm{ET}_{\mathrm{c}}$ \\
v. & $\mathrm{I}_{2} \mathrm{E}_{2}$ & Surface drip irrigation $+80 \%$ of $\mathrm{ET}_{\mathrm{c}}$ \\
vi. & $\mathrm{I}_{2} \mathrm{E}_{3}$ & Surface drip irrigation $+60 \%$ of $\mathrm{ET}_{\mathrm{c}}$ \\
\hline
\end{tabular}

The drip irrigation system, used in the orchard farm, included, an irrigation pump connected to sand and screen filters, and a hydraulic fertilizer injection pump. The main line is made of a PVC pipe of $63 \mathrm{~mm}$ diameter. Laterals of $16 \mathrm{~mm}$ diameter are connected to sub main line. Each later is $50 \mathrm{~m}$ long with standard drippers of $4 \mathrm{l} / \mathrm{h}$ discharge rate, spaced at $0.5 \mathrm{~m}$ apart. Two laterals served each row of guava trees.

Class A pan was used to determine the amount of applied irrigation water for the proposed irrigation treatments. Potential evapotranspiration (ETp) values were obtained from the class A pan method as follows:

$\mathrm{ET}_{\mathrm{p}}=\mathrm{E}_{\mathrm{pan}} \times \mathrm{K}_{\mathrm{pan}}$ (Doorenbos and Pruitt, 1984)

Where:

$\mathrm{E}_{\mathrm{pan}}$ : is pan evaporation rate ( $\mathrm{mm} /$ day)

$\mathrm{K}_{\text {pan }}$ : is pan coefficient. Its value depends on the relative humidity, wind speed and the site of the pan

$K_{\mathrm{pan}}$ value of 0.75 was used at the experimental site according to the weather condition.

\section{Soil water relations :}

Soil moisture content was gravimetrically determined in soil samples taken from consecutive depth of $20 \mathrm{~cm}$ each till $100 \mathrm{~cm}$ depth. These samples were taken just before each irrigation, 24 hours after irrigation and at harvesting to determine water consumptive use. Field capacity, wilting points and available soil moisture were determined in the field (Michael, 1978). The bulk density was determined by using the core method (Vomocil, 1957) to a depth of $100 \mathrm{~cm}$.The average values are presented in Table 2 . Some chemical and physical properties of the used soil were determined according to Black (1965) and Page et al. (1982) and the results obtained are presented in Table 3.

Table 2. The mean values of field capacity ( FC), wilting points( WP ), available soil moisture ( ASM ) and bulk density $\left(D_{b}\right)$ of the soil of the experimental farm

\begin{tabular}{ccccc}
\hline $\begin{array}{c}\text { Soil depth } \\
(\mathbf{~ c m})\end{array}$ & $\begin{array}{c}\text { FC } \\
(\mathbf{\%})\end{array}$ & $\begin{array}{c}\text { WP } \\
(\mathbf{\%})\end{array}$ & $\begin{array}{c}\text { ASM } \\
(\mathbf{\%})\end{array}$ & $\begin{array}{c}\mathbf{D}_{\mathbf{b}} \\
\left(\mathbf{g} / \mathbf{~ c m}^{\mathbf{3}}\right)\end{array}$ \\
\hline $0-20$ & 38.7 & 17.3 & 21.4 & 1.11 \\
$20-40$ & 37.5 & 16.7 & 20.8 & 1.13 \\
$20-60$ & 32.3 & 16.3 & 16.0 & 1.22 \\
$60-80$ & 29.9 & 15.1 & 14.8 & 1.27 \\
$80-100$ & 28.3 & 14.5 & 13.8 & 1.32 \\
Average & 33.3 & 16.0 & 17.4 & 1.21 \\
\hline
\end{tabular}

Table 3. The mean values of chemical and physical proprties of the soil of the experimental farm

\begin{tabular}{cccccccccc}
\hline $\begin{array}{c}\text { Soil } \\
\text { depth } \\
(\mathbf{~ c m ~})\end{array}$ & $\begin{array}{c}\mathbf{E C} \\
(\mathbf{d S} / \mathbf{m})\end{array}$ & $\begin{array}{c}\text { Chemical analysis } \\
\mathbf{p H}\end{array}$ & $\begin{array}{c}\mathbf{0 . M} \\
(\mathbf{\%})\end{array}$ & $\begin{array}{c}\mathbf{C a C O} 3 \\
\mathbf{( \% )}\end{array}$ & $\begin{array}{c}\text { Coarse } \\
\text { Sand }(\boldsymbol{\%})\end{array}$ & $\begin{array}{c}\text { Pine } \\
\text { Sand }(\boldsymbol{\%})\end{array}$ & $\begin{array}{c}\text { Silt } \\
(\boldsymbol{\%})\end{array}$ & $\begin{array}{c}\text { Clay } \\
(\boldsymbol{\%})\end{array}$ & Texture \\
\hline $0-20$ & 1.08 & 8.01 & 1.12 & 2.03 & 4.9 & 8.5 & 31.2 & 55.4 & Clay \\
$20-40$ & 1.01 & 7.93 & 1.01 & 1.76 & 7.9 & 10.5 & 29.4 & 52.2 & Clay \\
$20-60$ & 0.89 & 8.03 & 0.74 & 1.70 & 10.6 & 14.1 & 29.0 & 46.3 & Clay \\
$60-80$ & 0.79 & 7.82 & 0.64 & 1.55 & 12.9 & 15.5 & 27.1 & 44.5 & Clay \\
$80-100$ & 0.67 & 7.84 & 0.34 & 1.04 & 11.3 & 22.7 & 26.5 & 39.5 & Clay loam \\
Average & 0.89 & 7.93 & 0.77 & 1.62 & 9.5 & 14.3 & 28.6 & 47.6 & Clay \\
\hline
\end{tabular}




\section{Water consumptive use ( WCU):}

Water consumptive use was calculated using the following equation (Israelsen and Hansen, 1962).

$$
C u=\sum_{i=1}^{n} \frac{(\theta 2-\theta 1)}{100} \times D b X D i
$$

Where:

$\mathrm{Cu}=$ Water consumptive use $(\mathrm{cm})$, in effective root zone $(100 \mathrm{~cm})$.

$\mathrm{D}_{\mathrm{i}}=$ Soil layer depth $(20 \mathrm{~cm})$.

$\mathrm{D}_{\mathrm{b}}=$ Soil bulk density $\left(\mathrm{g} / \mathrm{cm}^{3}\right)$, of the specified soil layer.

$\theta 1=$ Soil moisture $\%$ before irrigation.

$\theta 2=$ Soil moisture $\%, 24$ hours after irrigation.

\section{Applied irrigation water ( AIW) :}

The amount of water applied per each irrigation was measured by flow meter in furrow irrigation and calculated according to the following equation in drip irrigation:

$$
A I W=\frac{\mathrm{ET0} \times \mathrm{Kc} \times \mathrm{Kr}}{\mathrm{Ea}}+L R
$$

Where:

AIW = Applied irrigation water depth (mm).

$\mathrm{ET}_{0}=$ Reference crop evapotranspiration $(\mathrm{mm} /$ day)

values obtained by class A pan evaporation method.

$\mathrm{K}_{\mathrm{c}}=$ Crop coefficient.

$\mathrm{K}_{\mathrm{r}}=$ Reduction factor that depends on ground cover. It equals 0.7 for mature plants.

$\mathrm{E}_{\mathrm{a}}=$ Irrigation efficiency $(\%)=0.85$.

$\mathrm{LR}=$ Leaching requirements $=10 \%$ of the total amount of water applied.

\section{Water use efficiency (WUE) :}

It was calculated according to the following equation (Vites, 1962 and Stanhill, 1986).

$$
\mathrm{WUE}=\frac{Y a}{A I W}
$$

Where:

WUE : water use efficiency $\left(\mathrm{kg} / \mathrm{m}^{3}\right)$.

$\mathrm{Y}_{\mathrm{a}} \quad$ : actual yield ( $\mathrm{kg} / \mathrm{fed}$.)

AIW : applied irrigation water $\left(\mathrm{m}^{3} / \mathrm{fed}\right)$

\section{Yield and chemical quality analysis:}

At the proper time, data were determined and registered as follows:

\section{Vegetative and flowering growth:}

The shoot lengths $(\mathrm{cm})$, number of leaves/ $\mathrm{m}$ and leaf area $\left(\mathrm{cm}^{2}\right)$ using planimeter were measured.

\section{Fruit characteristics and yield:}

Number of fruits $/ \mathrm{m}$, mean length and diameter of fruit $(\mathrm{cm})$, mean fruit size $\left(\mathrm{cm}^{3}\right)$, mean fruit weight $(\mathrm{g})$ and yield ( $\mathrm{kg} /$ tree) were measured..

\section{Fruit chemical properties:}

These properties included:

1. Total soluble solids (TSS \%) were determined by a bbe refractometer using the method of A.O.A.C. (1995).

2. Total acidity (\%) was determined by titration method as described by A.O.A.C. (1975).

3. TSS/acidity was calculated as a ratio.

4. Vitamin $\mathrm{C}$ (ascorbic acid) was determined by the method described by Horwitz (1970) as mg/100 g fruit flesh.

\section{Economic Analysis}

The prices in-puts and out-puts were calculated for the different treatments for guava. Concerning costs of irrigation in the two seasons for different treatments was calculated on the basis of rent of water. According to the marketing and employment conditions of the private orchard at Kafr El Dawar district, Beheira Governorate.

Total production costs (LE/fed.) was calculated according to the following equation:

Total production costs $(\mathrm{LE} / \mathrm{fed})=$. Irrigation system costs (fixed and running cost) + cost of cultivation (Preparation of soil, different agriculture practices, price of seed, labours and harvesting)

Total return (LE/fed): was calculated according to the following equation:

Total return $=$ Price $($ LE/ton $) \times$ Fruit yield (ton/fed)

Net return: was calculated according to the following equation:

Net return $=$ Total return - Total costs

Water productivity, $\left(\mathrm{WP}, \mathbf{L E} / \mathbf{m}^{3}\right)$ : was calculated by using the following formula:

$$
\begin{aligned}
& \text { Water productivity } \\
& =\frac{\text { Net return (LE } / \text { fed.) }}{\text { Amount of water applied }\left(\mathrm{m}^{3} / \mathrm{fed}\right)} \mathrm{LE} / \mathrm{m}^{3}
\end{aligned}
$$

\section{Statistical Analysis.}

The obtained data were subjected to statistical analysis of the least significance difference (LSD) at 5\% level of probability to compare treatment means when F-test was significant (SAS Institue, 1996). 


\section{RESULTS AND DISCUSSION}

\section{Vegetative growth parameters :}

Table 4 indicated that irrigation systems and water regime significantly affected all vegetative growth parameters of guava plants during the two growing seasons. The highest significant values were obtained as a result of drip irrigation and $100 \% \mathrm{ET}_{\mathrm{c}}$ treatment $\left(\mathrm{I}_{2} \mathrm{E}_{1}\right)$, followed by drip irrigation and $80 \% \mathrm{ET}_{\mathrm{c}}$ treatment $\left(\mathrm{T}_{2} \mathrm{E}_{2}\right)$ with non-significant differences between them. However, the lowest values were obtained as result of furrow irrigation and $60 \% \mathrm{ET}_{\mathrm{c}}\left(\mathrm{I}_{1} \mathrm{E}_{3}\right)$ treatment.

The mean values of shoot length were $21.9,21.2$, $16.3,23.6,23.3$ and $17.3 \mathrm{~cm}$ as result of the treatments $: \mathrm{I}_{1} \mathrm{E}_{1}, \mathrm{I}_{1} \mathrm{E}_{2}, \mathrm{I}_{1} \mathrm{E}_{3}, \mathrm{I}_{2} \mathrm{E}_{1}, \mathrm{I}_{2} \mathrm{E}_{2}$ and $\mathrm{I}_{2} \mathrm{E}_{3}$, respectively for the first growing season $(2017 / 2018)$ and were 20.8 , $20.4,16.8,23.3,22.8$ and $17.2 \mathrm{~cm}$ as result of the treatments : $\mathrm{I}_{1} \mathrm{E}_{1}, \mathrm{I}_{1} \mathrm{E}_{2}, \mathrm{I}_{1} \mathrm{E}_{3}, \mathrm{I}_{2} \mathrm{E}_{1}, \mathrm{I}_{2} \mathrm{E}_{2}$ and $\mathrm{I}_{2} \mathrm{E}_{3}$ ,respectively for the second growing season (2018/ 2019) .

The mean number of leaves $/ m$ were $84.3,78.3$, $65.2,100.5,93.4$ and 72.3 due to the treatments : $\mathrm{I}_{1} \mathrm{E}_{1}$, $\mathrm{I}_{1} \mathrm{E}_{2}, \mathrm{I}_{1} \mathrm{E}_{3}, \mathrm{I}_{2} \mathrm{E}_{1}, \mathrm{I}_{2} \mathrm{E}_{2}$ and $\mathrm{I}_{2} \mathrm{E}_{3}$, respectively for the growing season $2017 / 2018$ and were $91.8,86.2,62.3$, $103.4,97.6$ and 76.8 due to the treatments : $\mathrm{I}_{1} \mathrm{E}_{1}, \mathrm{I}_{1} \mathrm{E}_{2}$, $\mathrm{I}_{1} \mathrm{E}_{3}, \mathrm{I}_{2} \mathrm{E}_{1}, \mathrm{I}_{2} \mathrm{E}_{2}$ and $\mathrm{I}_{2} \mathrm{E}_{3}$, respectively for the growing season 2018/2019.

The mean values of leaf area $\left(\mathrm{cm}^{2}\right)$ were 49.10 , $46.30,36.20,52.40,50.30$ and $41.60 \mathrm{~cm}^{2}$ due to the treatments : $\mathrm{I}_{1} \mathrm{E}_{1}, \mathrm{I}_{1} \mathrm{E}_{2}, \mathrm{I}_{1} \mathrm{E}_{3}, \mathrm{I}_{2} \mathrm{E}_{1}, \mathrm{I}_{2} \mathrm{E}_{2}$ and $\mathrm{I}_{2} \mathrm{E}_{3}$ ,respectively for growing season $2017 / 2018$ and were $46.3,44.2,34.4,51.6,49.3$ and $37.2 \mathrm{~cm}^{2}$ due to the treatments : $\mathrm{I}_{1} \mathrm{E}_{1}, \mathrm{I}_{1} \mathrm{E}_{2}, \mathrm{I}_{1} \mathrm{E}_{3}, \mathrm{I}_{2} \mathrm{E}_{1}, \mathrm{I}_{2} \mathrm{E}_{2}$ and $\mathrm{I}_{2} \mathrm{E}_{3}$ ,respectively for growing season 2018/ 2019 .

These results are in harmony with those obtained by El-Dakroury (2008), who showed that increasing irrigation level from $60 \%$ up to $100 \% \mathrm{ET}_{\mathrm{c}}$ significantly increased the vegetative growth parameters of beans. This may be due to the role of water in increasing the uptake of nutrients from soil and translocation for photosynthetic assimilates. Thus, increasing in the leaf number and leaf area as well as foliage weight per plant (Leilah, 2009). Farooq et al. (2009) and Zhang and Huang (2013) reported that drought stress causes various physiologic and biochemical effects in plants. Mutava et al. (2015) found that the reduction in shoot fresh and dry biomass, shoot length, leaf area per soybean plant, transpiration rates, stomata conductance, photosynthetic rate, relative water content and leaf water potential were accompanied to drought water stress.

\section{Yield and Yield components}

\section{Yield of Guava:}

Table 5 showed that yield and yield components of guava were significantly affected $(\mathrm{P}<0.05)$ by irrigation systems and water regime. The yield of guava were $10.58,9.96,8.50,11.33,10.90$ and $9.32\left(\right.$ ton.fed $\left.^{-1}\right)$ due to the treatments: $\mathrm{I}_{1} \mathrm{E}_{1}, \mathrm{I}_{1} \mathrm{E}_{2}, \mathrm{I}_{1} \mathrm{E}_{3}, \mathrm{I}_{2} \mathrm{E}_{1}, \mathrm{I}_{2} \mathrm{E}_{2}$ and $\mathrm{I}_{2} \mathrm{E}_{3}$ ,respectively for the growing season 2017/ 2018 and were $10.32,9.53,7.52,11.05,10.33$ and 8.75 (ton.fed $^{-}$ $\left.{ }^{1}\right)$ due to the treatments : $\mathrm{I}_{1} \mathrm{E}_{1}, \mathrm{I}_{1} \mathrm{E}_{2}, \mathrm{I}_{1} \mathrm{E}_{3}, \mathrm{I}_{2} \mathrm{E}_{1}, \mathrm{I}_{2} \mathrm{E}_{2}$ and $\mathrm{I}_{2} \mathrm{E}_{3}$,respectively for the growing season 2018/2019 . The lowest guava yield was obtained as a result of $\mathrm{T}_{1} \mathrm{E}_{3}$ treatment (furrow irrigation and $60 \%$ of $\mathrm{ET}_{\mathrm{c}}$ ), which recorded 8.50 and 7.52 ton.fed $^{-1}$, respectively for the growing seasons 2017/ 2018 and 2018/ 2019. The highest guava yield was obtained as a result of $\mathrm{T}_{2} \mathrm{E}_{1}$ treatment (drip irrigation and $100 \%$ of $\mathrm{ET}_{\mathrm{c}}$ ), which recorded 11.33 and 11.05 ton.fed $^{-1}$, respectively for the growing season 2017/ 2018 and 2018/ 2019. These results are in harmony with those obtained by Biswas et al. (1999) and Patil and Patil (1999) who observed that at drip irrigation, the guava fruit yield was the highest when irrigated with $100 \%$ of $\mathrm{ET}_{\mathrm{c}}$.

\section{Yield components:}

The yield components were measured during each growth season for each treatment (Table 5). It is clear that yield components had significantly affected $(\mathrm{P}<$ 0.05 ) by irrigation systems and water regime.

The number of fruits/ $\mathrm{m}$ were $30.9,27.6,18.5$, $34.6,31.2$ and 22.3 due to the treatments : $\mathrm{I}_{1} \mathrm{E}_{1}, \mathrm{I}_{1} \mathrm{E}_{2}$, $\mathrm{I}_{1} \mathrm{E}_{3}, \mathrm{I}_{2} \mathrm{E}_{1}, \mathrm{I}_{2} \mathrm{E}_{2}$ and $\mathrm{I}_{2} \mathrm{E}_{3}$, respectively for the growing season $2017 / 2018$ and were $27.40,23.80,15.10,32.60$ , 29.50 and 19.6 due to the treatments : $\mathrm{I}_{1} \mathrm{E}_{1}, \mathrm{I}_{1} \mathrm{E}_{2}, \mathrm{I}_{1} \mathrm{E}_{3}$, $\mathrm{I}_{2} \mathrm{E}_{1}, \mathrm{I}_{2} \mathrm{E}_{2}$ and $\mathrm{I}_{2} \mathrm{E}_{3}$, respectively for the second growing season 2018/ 2019 (Table 5) . 
Table 4. Effect of irrigation systems and water regime on some vegetative growth parameters during the two growing seasons 2017/2018 and 2018/2019

\begin{tabular}{ccccccc}
\hline \multirow{2}{*}{ Treatments } & \multicolumn{2}{c}{ Shoot length $(\mathbf{~ c m})$} & \multicolumn{2}{c}{ No. of leaves / $\mathbf{~}$} & \multicolumn{2}{c}{ Leaf area $\left(\mathbf{c m}^{2}\right)$} \\
\cline { 2 - 7 } & $\mathbf{2 0 1 7 / 2 0 1 8}$ & $\mathbf{2 0 1 8 / 2 0 1 9}$ & $\mathbf{2 0 1 7 / 2 0 1 8}$ & $\mathbf{2 0 1 8} / \mathbf{2 0 1 9}$ & $\mathbf{2 0 1 7 / 2 0 1 8}$ & $\mathbf{2 0 1 8} / \mathbf{2 0 1 9}$ \\
\hline $\mathrm{I}_{1} \mathrm{E}_{1}$ & $21.9 \mathrm{~b}$ & $20.8 \mathrm{~b}$ & $84.3 \mathrm{~b}$ & $91.8 \mathrm{~b}$ & $49.1 \mathrm{~b}$ & $46.3 \mathrm{~b}$ \\
$\mathrm{I}_{1} \mathrm{E}_{2}$ & $21.2 \mathrm{~b}$ & $20.4 \mathrm{~b}$ & $78.3 \mathrm{~b}$ & $86.2 \mathrm{~b}$ & $46.3 \mathrm{~b}$ & $44.2 \mathrm{~b}$ \\
$\mathrm{I}_{1} \mathrm{E}_{3}$ & $16.3 \mathrm{~d}$ & $16.8 \mathrm{c}$ & $65.2 \mathrm{c}$ & $62.3 \mathrm{~d}$ & $36.2 \mathrm{~d}$ & $34.4 \mathrm{c}$ \\
$\mathrm{I}_{2} \mathrm{E}_{1}$ & $23.6 \mathrm{a}$ & $23.3 \mathrm{a}$ & $100.5 \mathrm{a}$ & $103.4 \mathrm{a}$ & $52.4 \mathrm{a}$ & $51.6 \mathrm{a}$ \\
$\mathrm{I}_{2} \mathrm{E}_{2}$ & $23.3 \mathrm{a}$ & $22.8 \mathrm{a}$ & $93.4 \mathrm{a}$ & $97.6 \mathrm{a}$ & $50.3 \mathrm{a}$ & $49.4 \mathrm{a}$ \\
$\mathrm{I}_{2} \mathrm{E}_{3}$ & $17.3 \mathrm{c}$ & $17.2 \mathrm{c}$ & $72.3 \mathrm{c}$ & $76.8 \mathrm{c}$ & $41.6 \mathrm{c}$ & $37.2 \mathrm{c}$ \\
$\mathrm{LSD}_{0.05}$ & 0.8 & 0.7 & 8.5 & 7.9 & 3.3 & 3.0 \\
\hline
\end{tabular}

Table 5. Effect of irrigation systems and water regime on yield and yield component of guava (Psidium Guavaja L.) during the two growing seasons 2017/2018 and 2018/2019

\begin{tabular}{cccccccc}
\hline Treatments & $\begin{array}{c}\text { Number of } \\
\text { fruits / lm }\end{array}$ & $\begin{array}{c}\text { Length of } \\
\text { fruit }(\mathbf{c m} \\
\text { ) }\end{array}$ & $\begin{array}{c}\text { Diameter of } \\
\text { fruit }(\mathbf{c m})\end{array}$ & $\begin{array}{c}\text { Fruit size } \\
\left(\mathbf{c m}^{\mathbf{3}}\right)\end{array}$ & $\begin{array}{c}\text { Fruit weight } \\
(\mathbf{g m})\end{array}$ & $\begin{array}{c}\text { Yield } \\
(\mathbf{t o n} / \mathbf{f e d})\end{array}$ & $\begin{array}{c}\text { Yield } \\
(\mathbf{k g} / \text { tree })\end{array}$ \\
\hline & & & $2017 / 2018$ & & & & \\
$\mathrm{I}_{1} \mathrm{E}_{1}$ & $30.9 \mathrm{~b}$ & $6.0 \mathrm{a}$ & $4.5 \mathrm{~b}$ & $48.0 \mathrm{~b}$ & $48.2 \mathrm{~b}$ & $10.6 \mathrm{~b}$ & $44.1 \mathrm{~b}$ \\
$\mathrm{I}_{1} \mathrm{E}_{2}$ & $27.6 \mathrm{bc}$ & $5.8 \mathrm{a}$ & $4.3 \mathrm{c}$ & $42.2 \mathrm{~b}$ & $42.3 \mathrm{c}$ & $10.0 \mathrm{~b}$ & $41.5 \mathrm{c}$ \\
$\mathrm{I}_{1} \mathrm{E}_{3}$ & $18.5 \mathrm{e}$ & $4.9 \mathrm{~b}$ & $4.1 \mathrm{c}$ & $35.0 \mathrm{c}$ & $35.6 \mathrm{c}$ & $8.5 \mathrm{~d}$ & $35.4 \mathrm{e}$ \\
$\mathrm{I}_{2} \mathrm{E}_{1}$ & $34.6 \mathrm{a}$ & $6.5 \mathrm{a}$ & $5.0 \mathrm{a}$ & $65.0 \mathrm{a}$ & $64.7 \mathrm{a}$ & $11.3 \mathrm{a}$ & $47.2 \mathrm{a}$ \\
$\mathrm{I}_{2} \mathrm{E}_{2}$ & $31.2 \mathrm{~b}$ & $6.1 \mathrm{a}$ & $4.7 \mathrm{~b}$ & $53.3 \mathrm{a}$ & $52.8 \mathrm{~b}$ & $10.9 \mathrm{a}$ & $45.4 \mathrm{a}$ \\
$\mathrm{I}_{2} \mathrm{E}_{3}$ & $22.3 \mathrm{~d}$ & $5.3 \mathrm{~b}$ & $4.2 \mathrm{c}$ & $38.0 \mathrm{c}$ & $38.2 \mathrm{c}$ & $9.2 \mathrm{c}$ & $38.5 \mathrm{~d}$ \\
$\mathrm{LSD}_{0.05}$ & 3.2 & 0.8 & 0.3 & 6.9 & 8.2 & 0.7 & 2.5 \\
\hline & & & $2018 / 2019$ & & & & \\
$\mathrm{I}_{1} \mathrm{E}_{1}$ & $27.4 \mathrm{~b}$ & $5.8 \mathrm{a}$ & $4.3 \mathrm{~b}$ & $42.2 \mathrm{~b}$ & $43.1 \mathrm{~b}$ & $10.3 \mathrm{~b}$ & $43.0 \mathrm{~b}$ \\
$\mathrm{I}_{1} \mathrm{E}_{2}$ & $23.8 \mathrm{c}$ & $5.6 \mathrm{~b}$ & $4.1 \mathrm{c}$ & $36.9 \mathrm{c}$ & $36.9 \mathrm{c}$ & $9.5 \mathrm{c}$ & $39.7 \mathrm{c}$ \\
$\mathrm{I}_{1} \mathrm{E}_{3}$ & $15.1 \mathrm{e}$ & $4.5 \mathrm{c}$ & $4.0 \mathrm{c}$ & $33.2 \mathrm{c}$ & $33.4 \mathrm{c}$ & $7.5 \mathrm{e}$ & $31.3 \mathrm{e}$ \\
$\mathrm{I}_{2} \mathrm{E}_{1}$ & $32.6 \mathrm{a}$ & $6.4 \mathrm{a}$ & $4.9 \mathrm{a}$ & $60.8 \mathrm{a}$ & $61.1 \mathrm{a}$ & $11.1 \mathrm{a}$ & $46.0 \mathrm{a}$ \\
$\mathrm{I}_{2} \mathrm{E}_{2}$ & $29.5 \mathrm{~b}$ & $6.0 \mathrm{a}$ & $4.5 \mathrm{~b}$ & $48.3 \mathrm{~b}$ & $49.1 \mathrm{~b}$ & $10.5 \mathrm{a}$ & $43.9 \mathrm{a}$ \\
$\mathrm{I}_{2} \mathrm{E}_{3}$ & $19.6 \mathrm{~d}$ & $5.2 \mathrm{~b}$ & $3.9 \mathrm{c}$ & $31.5 \mathrm{c}$ & $31.6 \mathrm{c}$ & $8.8 \mathrm{~d}$ & $36.5 \mathrm{~d}$ \\
$\mathrm{LSD}_{0.05}$ & 2.9 & 0.8 & 0.3 & 6.2 & 7.8 & 0.7 & 2.3 \\
\hline
\end{tabular}

The length of fruit were $6.0,5.8,4.9,6.5,6.1$ and $5.3 \mathrm{~cm}$ due to the treatments : $\mathrm{I}_{1} \mathrm{E}_{1}, \mathrm{I}_{1} \mathrm{E}_{2}, \mathrm{I}_{1} \mathrm{E}_{3}, \mathrm{I}_{2} \mathrm{E}_{1}$ , $\mathrm{I}_{2} \mathrm{E}_{2}$ and $\mathrm{I}_{2} \mathrm{E}_{3}$,respectively for the growing season $2017 / 2018$ and were $5.8,5.6,4.5,6.4,6.0$ and $5.2 \mathrm{~cm}$ due to the treatments : $\mathrm{I}_{1} \mathrm{E}_{1}, \mathrm{I}_{1} \mathrm{E}_{2}, \mathrm{I}_{1} \mathrm{E}_{3}, \mathrm{I}_{2} \mathrm{E}_{1}, \mathrm{I}_{2} \mathrm{E}_{2}$ and $\mathrm{I}_{2} \mathrm{E}_{3}$,respectively for the growing season 2018/ 2019 (Table 5) .

The diameter of fruit were $4.5,4.3,4.1,5.0,4.7$ and $4.2 \mathrm{~cm}$ due to the treatments: $\mathrm{I}_{1} \mathrm{E}_{1}, \mathrm{I}_{1} \mathrm{E}_{2}, \mathrm{I}_{1} \mathrm{E}_{3}, \mathrm{I}_{2} \mathrm{E}_{1}$ , $\mathrm{I}_{2} \mathrm{E}_{2}$ and $\mathrm{I}_{2} \mathrm{E}_{3}$, respectively for the growing season 2017/ 2018 and were $4.3,4.1,4.0,4.9,4.5$ and $3.9 \mathrm{~cm}$ due to the treatments : $\mathrm{I}_{1} \mathrm{E}_{1}, \mathrm{I}_{1} \mathrm{E}_{2}, \mathrm{I}_{1} \mathrm{E}_{3}, \mathrm{I}_{2} \mathrm{E}_{1}, \mathrm{I}_{2} \mathrm{E}_{2}$ and $\mathrm{I}_{2} \mathrm{E}_{3}$,respectively for the growing season 2018/ 2019 (Table 5) .

The mean values of Fruit size were $48.0,42.2$, $35.0,65.0,53.3$ and $38.0 \mathrm{~cm}^{3}$ due to the treatments: $I_{1} E_{1}, I_{1} E_{2}, I_{1} E_{3}, I_{2} E_{1}, I_{2} E_{2}$ and $I_{2} E_{3}$, respectively for growing season 2017/ 2018 and were 42.2 , 36.9, 33.2,
$60.8,48.3$ and $31.5 \mathrm{~cm}^{3}$ due to the treatments : $\mathrm{I}_{1} \mathrm{E}_{1}$, $\mathrm{I}_{1} \mathrm{E}_{2}, \mathrm{I}_{1} \mathrm{E}_{3}, \mathrm{I}_{2} \mathrm{E}_{1}, \mathrm{I}_{2} \mathrm{E}_{2}$ and $\mathrm{I}_{2} \mathrm{E}_{3}$, respectively for growing season 2018/ 2019 (Table 5) .

The mean values of fruit weight (gm.) were 48.2 , 42.3, 35.6, 64.7, 52.8 and $38.2 \mathrm{gm}$. due to he : $\mathrm{I}_{1} \mathrm{E}_{1}$, $\mathrm{I}_{1} \mathrm{E}_{2}, \mathrm{I}_{1} \mathrm{E}_{3}, \mathrm{I}_{2} \mathrm{E}_{1}, \mathrm{I}_{2} \mathrm{E}_{2}$ and $\mathrm{I}_{2} \mathrm{E}_{3}$, respectively for growing season 2017/ 2018 and were $43.1,36.9,33.4,61.1$, 49.1 and $31.6 \mathrm{gm}$. due to the treatments : $\mathrm{I}_{1} \mathrm{E}_{1}, \mathrm{I}_{1} \mathrm{E}_{2}$, $\mathrm{I}_{1} \mathrm{E}_{3}, \mathrm{I}_{2} \mathrm{E}_{1}, \mathrm{I}_{2} \mathrm{E}_{2}$ and $\mathrm{I}_{2} \mathrm{E}_{3}$, respectively for growing season 2018/2019 (Table 5) .

The mean values of yield of tree $(\mathrm{kg} /$ tree $)$ were $44.1,41.5,35.4,47.2,45.4$ and $38.5 \mathrm{~kg} . /$ tree due to the treatments : $\mathrm{I}_{1} \mathrm{E}_{1}, \mathrm{I}_{1} \mathrm{E}_{2}, \mathrm{I}_{1} \mathrm{E}_{3}, \mathrm{I}_{2} \mathrm{E}_{1}, \mathrm{I}_{2} \mathrm{E}_{2}$ and $\mathrm{I}_{2} \mathrm{E}_{3}$ ,respectively for the growing season $2017 / 2018$ and were $43.0,39.7,31.3,46.0,43.9$ and $36.5 \mathrm{~kg}$./tree due to the treatments: $\mathrm{I}_{1} \mathrm{E}_{1}, \mathrm{I}_{1} \mathrm{E}_{2}, \mathrm{I}_{1} \mathrm{E}_{3}, \mathrm{I}_{2} \mathrm{E}_{1}, \mathrm{I}_{2} \mathrm{E}_{2}$ and $\mathrm{I}_{2} \mathrm{E}_{3}$ ,respectively for the growing season 2018/ 2019 (Table $5)$. The obtained results are in agreement with those 
obtained by Kumar et al. (2009), Boora et al. (2002) and Singh et al. (2005).

Reference Evapotranspiration (ET), Actual or Crop Evapotranspiration ( $\left.\mathbf{E T}_{\mathbf{c}}\right)$ and Irrigation Requirements (IR.)

Table 6 showed that the values of reference or potential evapotranspiration (ET0 or $\mathrm{ET}_{\mathrm{p}}$ ) are affected by the climatic factors, and has $\mathrm{ET}_{0}$ increased in summer and decreased in winter. Maximum values of $\mathrm{ET}_{0}$ or $\mathrm{ET}_{\mathrm{p}}$ were found in July (5.69 and $5.73 \mathrm{~mm} /$ day) in 2017 / 2018 and 2018 / 2019 seasons, respectively. Minimum value of $\mathrm{ET}_{0}$ or $\mathrm{ET}_{\mathrm{p}}$ was found in December $2017 / 2018$ (1.50 mm/day) while minimum value of $\mathrm{ET}_{0}$ (1.48 mm/day) was found in January 2018/2019.

It is clear from the obtained data, that daily and monthly crop or actual evapotranspiration $\left(\mathrm{ET}_{\mathrm{c}}\right)$ had the same behavior as reference evapotranspiration $\left(\mathrm{ET}_{0}\right)$, where the values of daily and monthly $\mathrm{ET}_{\mathrm{c}}$ had increased in summer and decreased in winter. Maximum values of daily $\mathrm{ET}_{\mathrm{a}}$ or $\mathrm{ET}_{\mathrm{c}}$ were found in July (4.78 and
$4.81 \mathrm{~mm} /$ day) in 2017 / 2018 and 2018 / 2019 seasons, respectively. Minimum values of daily $\mathrm{ET}_{\mathrm{a}}$ or $\mathrm{ET}_{\mathrm{c}}$ were found in December $(0.83$ and $0.87 \mathrm{~mm} /$ day in 2017 / 2018 and 2018 / 2019 seasons, respectively). Cumulative crop evapotranspiration in the first growing season (2017/2018) was $1060.29 \mathrm{~mm}$, while in second growing season (2018/2019) was $1043 \mathrm{~mm}$. These findings agreed with the data obtained by Gad El-Rab et al. (1993), Attia et al. (1994) and Abbas and Anton (1999).

Table 6 showed that irrigation requirements of guava had ascending values during January - July and descending values during August - December. Cumulative irrigation requirements (IR.) of the first growing season (2017/2018) recorded $963.59 \mathrm{~mm}$, while in the second growing season (2018/2019) it recorded $922 \mathrm{~mm}$. The obtained results are in agreement with those obtained by Pouget (1981), Kliewer (1977), Kliewer (1971) and Kliewer and Schultz (1973).

Table 6. Monthly reference evapotranspiration $\left(\mathrm{ET}_{\mathbf{0}}\right)$, crop evapotranspiration, effective rainfall and irrigation requirements during the two growing seasons: 2017 / 2018 and 2018 / 2019

\begin{tabular}{|c|c|c|c|c|c|c|}
\hline Months & $\begin{array}{c}\text { ETo } \\
\text { ( mm/ day) }\end{array}$ & $\mathbf{K}_{\mathbf{c}}$ & $\begin{array}{c}\text { ETc } \\
(\mathbf{m m} / \text { day }) \\
\end{array}$ & $\begin{array}{c}\text { ETc } \\
(\mathrm{mm} / \mathrm{month}) \\
\end{array}$ & $\begin{array}{c}\text { Effective Rainfall } \\
(\mathrm{mm} / \mathrm{month})\end{array}$ & $\begin{array}{c}\text { Irr. Req. } \\
(\mathrm{mm} / \text { month })\end{array}$ \\
\hline \multicolumn{7}{|c|}{$2017 / 2018$} \\
\hline Jan. & 1.52 & 0.85 & 1.29 & 39.99 & 13.60 & 26.39 \\
\hline Feb. & 2.19 & 0.85 & 1.86 & 52.08 & 11.80 & 40.28 \\
\hline Mar. & 3.14 & 0.85 & 2.67 & 82.77 & 1.50 & 81.27 \\
\hline Apr. & 4.09 & 0.86 & 3.52 & 105.60 & 2.80 & 102.80 \\
\hline May & 4.97 & 0.86 & 4.27 & 132.37 & 0.00 & 132.37 \\
\hline June & 5.43 & 0.86 & 4.67 & 140.09 & 0.00 & 140.09 \\
\hline July & 5.69 & 0.84 & 4.78 & 148.17 & 1.70 & 146.47 \\
\hline Aug. & 5.38 & 0.81 & 4.36 & 135.16 & 0.00 & 135.16 \\
\hline Sep. & 4.52 & 0.70 & 3.16 & 94.80 & 0.00 & 94.80 \\
\hline Oct. & 3.23 & 0.66 & 2.13 & 66.03 & 10.90 & 55.13 \\
\hline Nov. & 2.09 & 0.60 & 1.25 & 37.50 & 22.50 & 15.00 \\
\hline Dec. & 1.50 & 0.55 & 0.83 & 25.73 & 46.80 & $(-21.07)$ \\
\hline$\sum$ & & & & 1060.29 & 111.70 & 963.59 \\
\hline \multicolumn{7}{|c|}{$2018 / 2019$} \\
\hline Jan. & 1.48 & 0.85 & 1.26 & 35.28 & 24.00 & 11.08 \\
\hline Feb. & 2.08 & 0.85 & 1.77 & 49.50 & 14.00 & 35.00 \\
\hline Mar. & 2.96 & 0.85 & 2.52 & 78.00 & 24.30 & 53.7 \\
\hline Apr. & 3.88 & 0.86 & 3.35 & 100.50 & 3.50 & 97.00 \\
\hline May & 4.71 & 0.86 & 4.05 & 125.55 & 0.00 & 125.55 \\
\hline June & 5.57 & 0.86 & 4.79 & 143.71 & 0.00 & 143.71 \\
\hline July & 5.73 & 0.84 & 4.48 & 149.21 & 0.00 & 149.21 \\
\hline Aug. & 5.44 & 0.81 & 4.41 & 136.71 & 0.00 & 136.71 \\
\hline Sep. & 4.46 & 0.70 & 3.12 & 93.66 & 0.00 & 93.66 \\
\hline Oct. & 3.22 & 0.66 & 2.13 & 66.03 & 17.40 & 48.63 \\
\hline Nov. & 2.15 & 0.60 & 1.29 & 38.70 & 0.20 & 38.50 \\
\hline Dec. & 1.58 & 0.55 & 0.87 & 26.97 & 37.60 & $-10.63)($ \\
\hline$\Sigma$ & & & & 1043 & 121 & 922 \\
\hline
\end{tabular}




\section{Amount of applied irrigation water and crop water use efficiency :}

\section{Amount of applied irrigation water (AIW)}

Table 7 showed that the amount of AIW, for the treatments $\mathrm{I}_{1} \mathrm{E}_{1}, \mathrm{I}_{1} \mathrm{E}_{2}$ and $\mathrm{I}_{1} \mathrm{E}_{3}$ have recorded 1550.39, 1240.31 and $930.23 \mathrm{~mm}$. respectively in the $1^{\text {st }}$ growing season, and 1474.90, 1179.94 and $884.95 \mathrm{~mm}$. respectively in the $2^{\text {nd }}$ growing season. The results of AIW for the treatments $\mathrm{I}_{2} \mathrm{E}_{1}, \mathrm{I}_{2} \mathrm{E}_{2}$ and $\mathrm{I}_{2} \mathrm{E}_{3}$ were $1138.88,911.10$ and $683.33 \mathrm{~mm}$. respectively in the $1^{\text {st }}$ growing season, and were $1040.15,832.13$ and 624.09 $\mathrm{mm}$. respectively in the $2^{\text {nd }}$ growing season.

At the beginning of the growing season, the amount of applied water was low then and increased due to increasing vegetative growth of guava plant. However, the amounts of applied water declined at maturity.
Maximum value of AIW (249.18 $\mathrm{mm} \mathrm{/}$ month) for guava trees was recorded in July at 2018/ 2019 by applying $100 \%$ of $\mathrm{ET}_{\mathrm{c}}$ and furrow irrigation $\left(\mathrm{I}_{1} \mathrm{E}_{1}\right)$, while minimum value of AIW (24.78 $\mathrm{mm} /$ month) occurred in February at the growing season $2018 / 2019$ by applying $60 \%$ of $\mathrm{ET}_{\mathrm{c}}$ and drip irrigation $\left(\mathrm{I}_{2} \mathrm{E}_{3}\right)$.These results are in agreement with those reported by Ekren et al. (2012) and Ibrahim (2003).

\section{Water use efficiency(WUE):}

The furrow irrigation method used higher amounts of water than drip irrigation method (Table 8). Water use efficiency of drip-irrigated treatment was higher and differed from furrow irrigated treatment in the two growth seasons $(\mathrm{P}<0.05)$. Maximum water use efficiency $\left(3.34 \mathrm{~kg} . \mathrm{m}^{-3}\right)$ was recorded in guava trees as a result of $\mathrm{I}_{2} \mathrm{E}_{3}$ treatment $\left(60 \% \mathrm{ET}_{\mathrm{c}}+\right.$ drip irrigation) in the $2^{\text {nd }}$ season 2018/2019 (Fig.1).

Table7. Applied irrigation water (AIW, mm / month) for guava trees, as affected by irrigation systems and water regime during the two growing seasons ,2017 /2018 and 2018 /2019

\begin{tabular}{|c|c|c|c|c|c|c|}
\hline \multirow[b]{2}{*}{ Month } & \multicolumn{3}{|c|}{ Furrow Irrigation $\left(\mathbf{I}_{1}\right)$} & \multicolumn{3}{|c|}{ Drip Irrigation ( $\left.\mathbf{I}_{2}\right)$} \\
\hline & $\begin{array}{c}100 \% \mathbf{E T}_{\mathbf{c}} \\
\left(\mathrm{E}_{1}\right)\end{array}$ & $\begin{array}{c}80 \% \mathbf{E T}_{\mathbf{c}} \\
\left(\mathbf{E}_{2}\right)\end{array}$ & $\begin{array}{c}60 \% \mathbf{E T}_{\mathbf{c}} \\
\left(\mathbf{E}_{3}\right)\end{array}$ & $\begin{array}{c}100 \% \mathbf{E T}_{\mathbf{c}} \\
\left(\mathrm{E}_{1}\right)\end{array}$ & $\begin{array}{c}80 \% \mathbf{E T}_{\mathbf{c}} \\
\left(\mathrm{E}_{2}\right)\end{array}$ & $\begin{array}{c}60 \% \mathbf{E T}_{\mathbf{c}} \\
\left(\mathbf{E}_{3}\right)\end{array}$ \\
\hline \multicolumn{7}{|c|}{$2017 / 2018$} \\
\hline Jan. & \multicolumn{6}{|c|}{ Without Irrigation } \\
\hline Feb. & 67.27 & 53.82 & 40.12 & 47.35 & 37.88 & 28.41 \\
\hline Mar. & 135.72 & 108.58 & 81.43 & 95.90 & 76.72 & 57.54 \\
\hline Apr. & 171.68 & 137.34 & 103.01 & 121.3 & 97.04 & 58.22 \\
\hline May & 221.06 & 176.85 & 132.64 & 156.20 & 124.96 & 93.72 \\
\hline June & 233.95 & 187.16 & 140.37 & 165.31 & 132.25 & 99.19 \\
\hline July & 244.60 & 195.68 & 146.76 & 172.83 & 138.26 & 103.70 \\
\hline Aug. & 225.72 & 180.58 & 135.43 & 159.49 & 127.59 & 95.69 \\
\hline Sep. & 158.32 & 126.66 & 94.99 & 111.86 & 89.49 & 67.12 \\
\hline Oct. & 92.07 & 73.66 & 55.24 & 108.64 & 86.91 & 65.18 \\
\hline Nov. & \multirow{2}{*}{\multicolumn{6}{|c|}{$\begin{array}{l}\text { Without Irrigation } \\
\text { Without Irrigation }\end{array}$}} \\
\hline Dec. & & & & & & \\
\hline$\sum$ & 1550.39 & 1240.31 & 930.23 & 1138.88 & 911.10 & 683.33 \\
\hline \multicolumn{7}{|c|}{$2018 / 2019$} \\
\hline Jan. & \multicolumn{6}{|c|}{ Without Irrigation } \\
\hline Feb. & 58.45 & 46.76 & 35.07 & 41.30 & 33.04 & 24.78 \\
\hline Mar. & 89.68 & 71.74 & 53.81 & 63.37 & 50.70 & 38.02 \\
\hline Apr. & 161.99 & 129.59 & 97.19 & 114.46 & 91.57 & 68.68 \\
\hline May & 209.67 & 167.74 & 125.80 & 146.15 & 116.92 & 87.69 \\
\hline June & 240.00 & 192.00 & 144.00 & 169.58 & 135.66 & 101.75 \\
\hline July & 249.18 & 199.34 & 149.51 & 176.07 & 140.86 & 105.64 \\
\hline Aug. & 228.31 & 182.65 & 136.99 & 161.32 & 129.06 & 96.79 \\
\hline Sep. & 156.41 & 125.13 & 93.85 & 110.52 & 88.42 & 66.31 \\
\hline Oct. & 81.21 & 64.99 & 48.73 & 57.38 & 45.90 & 34.43 \\
\hline Nov. & \multirow{2}{*}{\multicolumn{6}{|c|}{$\begin{array}{l}\text { Without Irrigation } \\
\text { Without Irrigation }\end{array}$}} \\
\hline Dec. & & & & & & \\
\hline$\sum$ & 1474.90 & 1179.94 & 884.95 & 1040.15 & 832.13 & 624.09 \\
\hline
\end{tabular}


Table 8. The mean values of water use efficiency (WUE) mean values, as affected by irrigation systems and water regime during the two growing seasons

\begin{tabular}{ccc}
\hline \multirow{2}{*}{ Treatments } & \multicolumn{2}{c}{ Water use efficiency $\left(\mathbf{k g} / \mathbf{m}^{\mathbf{3}}\right)$} \\
\cline { 2 - 3 } & $\mathbf{1}^{\mathbf{S T}}$ season & $\mathbf{2}^{\text {nd }}$ season \\
\hline $\mathrm{I}_{1} \mathrm{E}_{1}$ & 1.63 & 1.67 \\
$\mathrm{I}_{1} \mathrm{E}_{2}$ & 1.91 & 1.92 \\
$\mathrm{I}_{1} \mathrm{E}_{3}$ & 2.18 & 2.03 \\
$\mathrm{I}_{2} \mathrm{E}_{1}$ & 2.37 & 2.53 \\
$\mathrm{I}_{2} \mathrm{E}_{2}$ & 2.58 & 3.02 \\
$\mathrm{I}_{2} \mathrm{E}_{3}$ & 3.23 & 3.34 \\
$\mathrm{LSD}_{0.05}$ & 0.21 & 0.18 \\
\hline
\end{tabular}

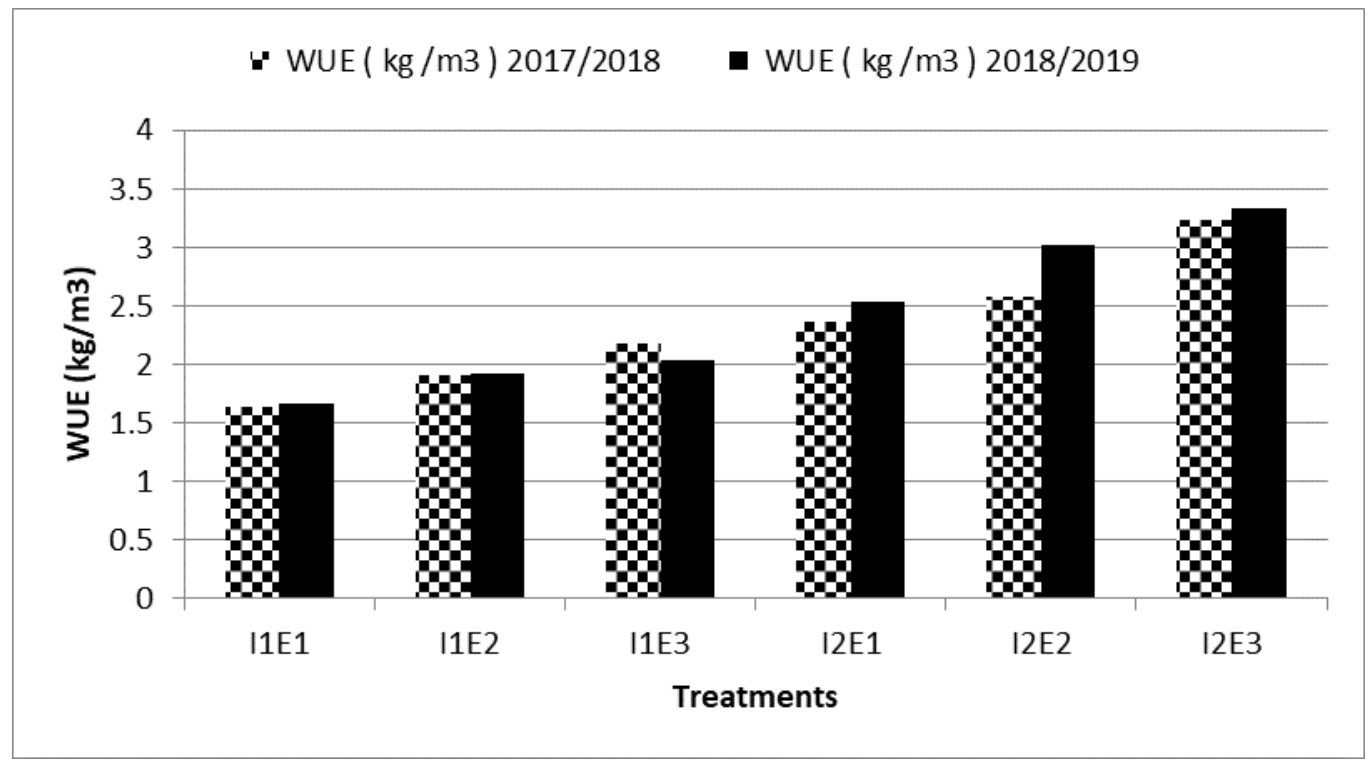

Fig 1. Effect of irrigation systems and water regime on crop water use efficiency $\left(\mathrm{kg} / \mathrm{m}^{3}\right)$ of guava (Psidium Guavaja L.) during the two growing seasons (2017 / 2018 and 2018 / 2019)

Water use efficiency ranged from 1.63 to 3.34 $\mathrm{kg} . \mathrm{m}^{-3}$ and increased with the decreasing applied water in the two growing seasons. Alaa et al. (2012) concluded that WUE increased from 5.129 to 7.379 $\mathrm{kg} \cdot \mathrm{m}^{-3}$ for furrow- irrigated treatment, and from 6.907 to $10.257 \mathrm{~kg} . \mathrm{m}^{-3}$ for drip-irrigated treatments.

\section{Fruit chemical composition}

The chemical analysis of guava fruits included; total soluble solids (TSS \%), acidity ( \%), TSS / Acidity ratio and vitamin $\mathrm{C}(\mathrm{mg} / 100 \mathrm{~g}$ pulp $)$ and were shown in Table 9 and Figs 2 and 3.

\section{Total soluble solids (TSS \%):}

The mean values of TSS were $11.75,11.32,10.99$ $, 12.23,11.99$ and $11.02 \%$ due to the treatments : $\mathrm{I}_{1} \mathrm{E}_{1}$, $\mathrm{I}_{1} \mathrm{E}_{2}, \mathrm{I}_{1} \mathrm{E}_{3}, \mathrm{I}_{2} \mathrm{E}_{1}, \mathrm{I}_{2} \mathrm{E}_{2}$ and $\mathrm{I}_{2} \mathrm{E}_{3}$, respectively for the growing season 2017/ 2018 and were 11.72 , 11.16, $10.65,12.62,12.03$ and $10.42 \%$ due to the treatments :
$\mathrm{I}_{1} \mathrm{E}_{1}, \mathrm{I}_{1} \mathrm{E}_{2}, \mathrm{I}_{1} \mathrm{E}_{3}, \mathrm{I}_{2} \mathrm{E}_{1}, \mathrm{I}_{2} \mathrm{E}_{2}$ and $\mathrm{I}_{2} \mathrm{E}_{3}$, respectively for the growing season 2018/2019 . Maximum TSS (12.62 $\%$ ) was recorded in guava trees due to the $\mathrm{I}_{2} \mathrm{E}_{1}$ treatment $\left(100 \% \mathrm{ET}_{\mathrm{c}}+\right.$ drip irrigation $)$ in the $2^{\text {nd }}$ season $2018 / 2019$.

Acidity (\%):

The mean values of acidity were $0.48,0.45,0.36$, $0.53,0.48$ and $0.43 \%$ due to the treatments : $\mathrm{I}_{1} \mathrm{E}_{1}, \mathrm{I}_{1} \mathrm{E}_{2}$, $\mathrm{I}_{1} \mathrm{E}_{3}, \mathrm{I}_{2} \mathrm{E}_{1}, \mathrm{I}_{2} \mathrm{E}_{2}$ and $\mathrm{I}_{2} \mathrm{E}_{3}$, respectively for the $1^{\text {st }}$ growing season $(2017 / 2018)$ and were $0.44,0.41,0.35,0.49$, 0.46 and $0.37 \%$ due to the treatments : $\mathrm{I}_{1} \mathrm{E}_{1}, \mathrm{I}_{1} \mathrm{E}_{2}, \mathrm{I}_{1} \mathrm{E}_{3}$, $\mathrm{I}_{2} \mathrm{E}_{1}, \mathrm{I}_{2} \mathrm{E}_{2}$ and $\mathrm{I}_{2} \mathrm{E}_{3}$, respectively for the $2^{\text {nd }}$ growing season (2018/ 2019) . The maximum acidity $(0.53 \%)$ was recorded in guava trees due to the $\mathrm{I}_{2} \mathrm{E}_{1}$ treatment $\left(100 \% \mathrm{ET}_{\mathrm{c}}+\right.$ drip irrigation $)$ in the $2^{\text {nd }}$ season $2018 / 2019$. 


\section{TSS / Acidity ratio:}

The mean values of this ratio were $24.48,25.16$, $29.92,23.08,24.98$ and 25.65 due to the treatments : $\mathrm{I}_{1} \mathrm{E}_{1}, \mathrm{I}_{1} \mathrm{E}_{2}, \mathrm{I}_{1} \mathrm{E}_{3}, \mathrm{I}_{2} \mathrm{E}_{1}, \mathrm{I}_{2} \mathrm{E}_{2}$ and $\mathrm{I}_{2} \mathrm{E}_{3}$, respectively for the $1^{\text {st }}$ growing season $(2017 / 2018)$ and were 26.64 , $27.21,30.43,25.76,26.15$ and 28.16 due to the treatments : $\mathrm{I}_{1} \mathrm{E}_{1}, \mathrm{I}_{1} \mathrm{E}_{2}, \mathrm{I}_{1} \mathrm{E}_{3}, \mathrm{I}_{2} \mathrm{E}_{1}, \mathrm{I}_{2} \mathrm{E}_{2}$ and $\mathrm{I}_{2} \mathrm{E}_{3}$ ,respectively for the $2^{\text {nd }}$ growing season 2018/ 2019 .
Maximum TSS / Acidity ratio (30.43) was recorded in guava trees under $\mathrm{I}_{1} \mathrm{E}_{3}$ the treatment $\left(60 \% \mathrm{ET}_{\mathrm{c}}+\right.$ furrow irrigation) in the $1^{\text {st }}$ season $(2017 / 2018)$ and the minimum TSS / Acidity ratio (23.08) was recorded in guava trees under $\mathrm{I}_{2} \mathrm{E}_{1}$ the treatment $\left(100 \% \mathrm{ET}_{\mathrm{c}}+\right.$ drip irrigation) in the $2^{\text {nd }}$ season $2018 / 2019$.

Table 9. Effect of irrigation systems and water regime on chemical composition of guava (Psidium Guavaja L.) during the two growing seasons: 2017 / 2018 and 2018 / 2019

\begin{tabular}{ccccc}
\hline Treatments & TSS ( \% ) & Acidity ( \% ) & $\begin{array}{c}\text { TSS / acidity } \\
\text { Ratio }\end{array}$ & $\begin{array}{c}\text { Vitamin C } \\
\text { ( mg /100 g pulp) }\end{array}$ \\
\hline & 11.75 & $2017 / 2018$ & & \\
$\mathrm{I}_{1} \mathrm{E}_{1}$ & 11.32 & 0.48 & 24.48 & 47.44 \\
$\mathrm{I}_{1} \mathrm{E}_{2}$ & 10.77 & 0.45 & 25.16 & 47.21 \\
$\mathrm{I}_{1} \mathrm{E}_{3}$ & 12.23 & 0.36 & 29.92 & 46.09 \\
$\mathrm{I}_{2} \mathrm{E}_{1}$ & 11.99 & 0.53 & 23.08 & 49.46 \\
$\mathrm{I}_{2} \mathrm{E}_{2}$ & 11.02 & 0.48 & 24.98 & 48.21 \\
$\mathrm{I}_{2} \mathrm{E}_{3}$ & $\mathrm{NS}$ & $\mathrm{NS}$ & 25.14 & 46.54 \\
$\mathrm{LSD}_{0.05}$ & 11.72 & $2018 / 2019$ & $\mathrm{NS}$ & 1.96 \\
\hline & 0.44 & 26.64 & \\
$\mathrm{I}_{1} \mathrm{E}_{1}$ & 11.16 & 0.41 & 27.21 & 49.52 \\
$\mathrm{I}_{1} \mathrm{E}_{2}$ & 10.65 & 0.35 & 30.43 & 48.42 \\
$\mathrm{I}_{1} \mathrm{E}_{3}$ & 12.62 & 0.49 & 25.76 & 56.51 \\
$\mathrm{I}_{2} \mathrm{E}_{1}$ & 12.03 & 0.46 & 26.15 & 49.34 \\
$\mathrm{I}_{2} \mathrm{E}_{2}$ & 10.42 & 0.37 & 28.16 & 46.79 \\
$\mathrm{I}_{2} \mathrm{E}_{3}$ & $\mathrm{NS}$ & $\mathrm{NS}$ & $\mathrm{NS}$ & 2.03 \\
$\mathrm{LS}_{0.05}$ & & & \\
\hline
\end{tabular}

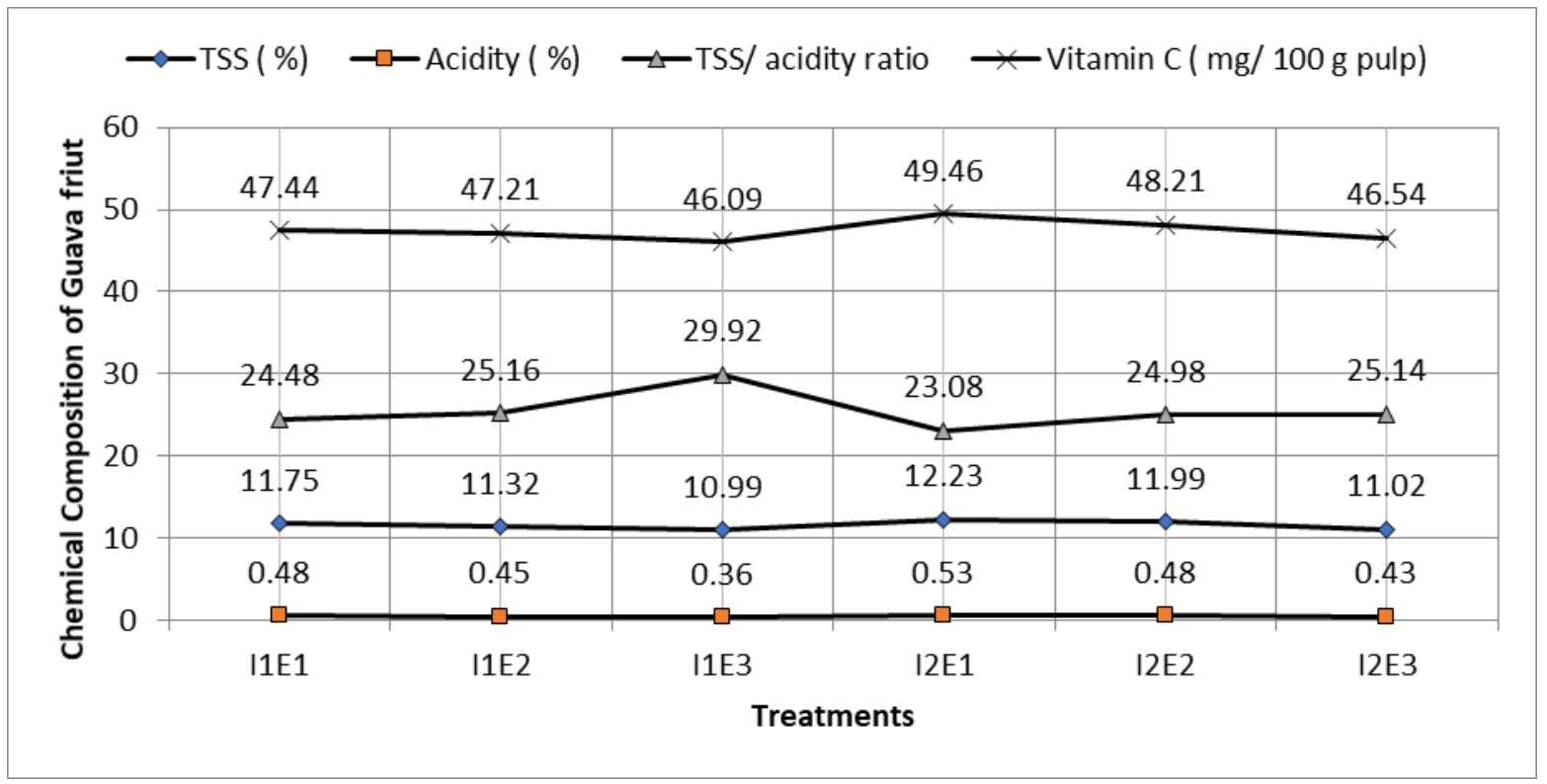

Fig 2. Effect of irrigation systems and water regime on chemical composition of guava (Psidium Guavaja $\mathbf{L}$.) during the first growing season 2017 / 2018 


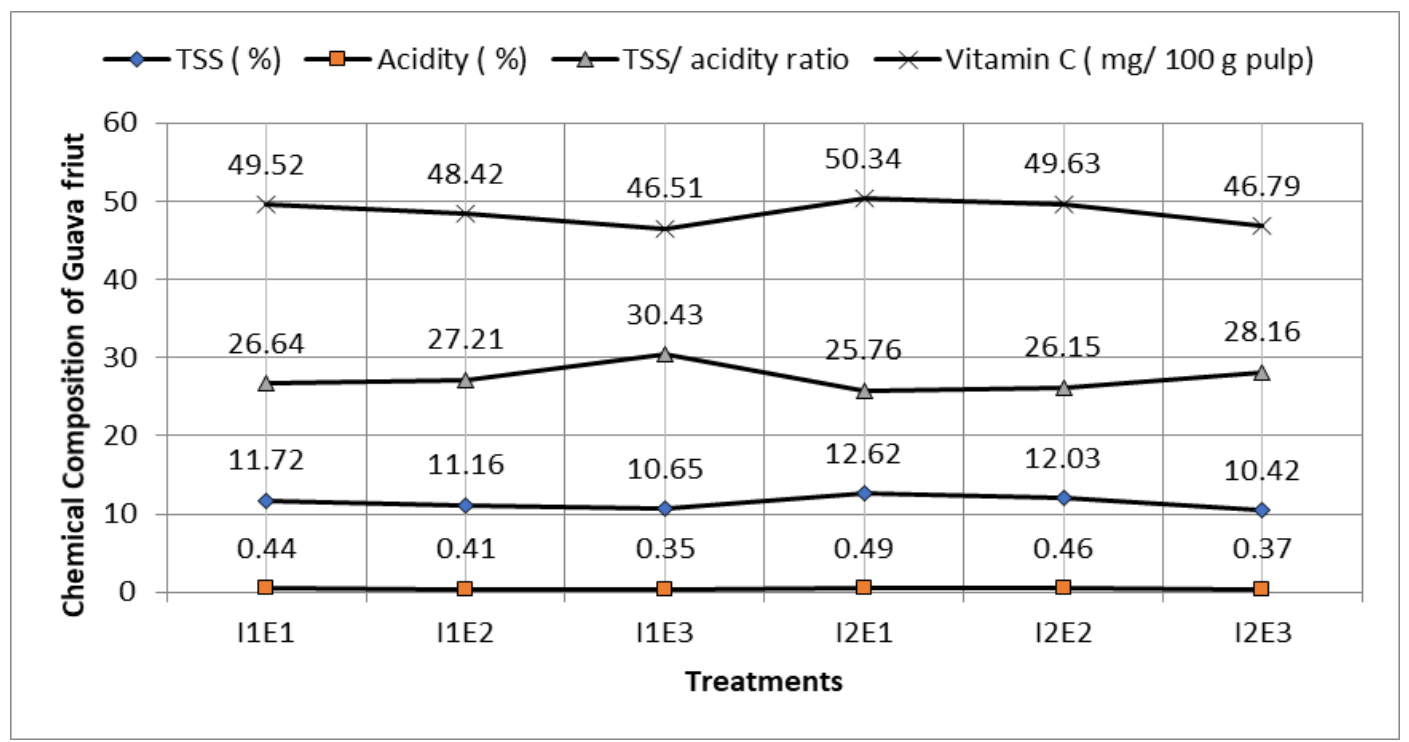

Fig 3. Effect of irrigation systems and water regime on chemical composition of guava (Psidium Guavaja L.) during the second growing season 2018 / 2019

\section{Vitamin C ( mg / $100 \mathrm{~g}$ pulp ) :}

The obtained data for vitamin $C$ showed, that significant effect of irrigation systems and water regime during growing seasons 2017 / 2018 and 2018 / 2019 (Table 9) . The highest vitamin $\mathrm{C}$ content was found under $\mathrm{I}_{2} \mathrm{E}_{1}$ and $\mathrm{I}_{2} \mathrm{E}_{3}$ treatments and recorded 49.46 and $48.21 \mathrm{mg} / 100 \mathrm{~g}$ pulp in the $1^{\text {st }}$ growing season , respectively and recorded 51.34 and $49.63(\mathrm{mg} / 100 \mathrm{~g}$ pulp ) in the $2^{\text {nd }}$ growing season, respectively. The lowest vitamin $\mathrm{C}$ content was found under $\mathrm{I}_{1} \mathrm{E}_{3}$ and recorded $45.09 \mathrm{mg} / 100 \mathrm{~g}$ pulp in the $1^{\text {st }}$ growing season, while in the $2^{\text {nd }}$ growing season was the lowest value under $\mathrm{I}_{2} \mathrm{E}_{3}$ and recorded $46.79 \mathrm{mg} / 100 \mathrm{~g}$ pulp.
Our results can be confirmed by those found by Khattab et al. (2011) and Lawand and Patil (1996) who found non-significant effect of different water regimes on TSS (\%), acidity ( $\%$ ), while significant effect on Ascorbic acid .

\section{Economic Analysis}

Table 10 and Figs 4 and 5 showed that total cost of guava production has been affected by the various treatments which can be arranged as follows: $I_{1} E_{1}>I_{2} E_{1}$ $>\mathrm{I}_{1} \mathrm{E}_{2}>\mathrm{I}_{2} \mathrm{E}_{2}>\mathrm{I}_{2} \mathrm{E}_{3}>\mathrm{I}_{1} \mathrm{E}_{3}$ in the $1^{\text {st }}$ season, and was $I_{1} E_{1}>I_{2} E_{1}>I_{2} E_{1}>I_{1} E_{3}>I_{2} E_{2}>I_{2} E_{3}$ in $2^{\text {nd }}$ season .

Table 10. Economic analysis of guava grown under irrigation systems and water regime treatments during the two growing seasons (2017 / 2018 and 2018 / 2019)

\begin{tabular}{ccccc}
\hline Treatments & $\begin{array}{c}\text { Total cost } \\
\text { ( LE/fed. })\end{array}$ & $\begin{array}{c}\text { Total return } \\
\text { ( LE/fed.) }\end{array}$ & $\begin{array}{c}\text { Net return } \\
\text { ( LE/fed. })\end{array}$ & $\begin{array}{c}\text { W.P. } \\
\left(\mathbf{L E} / \mathbf{m}^{\mathbf{3}}\right)\end{array}$ \\
\hline & 10510 & $2017 / 2018$ & & \\
$\mathrm{I}_{1} \mathrm{E}_{1}$ & 9208 & 31740 & 21230 & 3.26 \\
$\mathrm{I}_{1} \mathrm{E}_{2}$ & 8279 & 24900 & 15690 & 3.01 \\
$\mathrm{I}_{1} \mathrm{E}_{3}$ & 9279 & 17000 & 8721 & 2.23 \\
$\mathrm{I}_{2} \mathrm{E}_{1}$ & 8326 & 33990 & 24711 & 5.16 \\
$\mathrm{I}_{2} \mathrm{E}_{2}$ & 8357 & 27250 & 18924 & 4.95 \\
$\mathrm{I}_{2} \mathrm{E}_{3}$ & 18460 & 10103 & 3.52 \\
\hline & 10174 & $2018 / 2019$ & & \\
$\mathrm{I}_{1} \mathrm{E}_{1}$ & 8952 & 30960 & 20786 & 3.37 \\
$\mathrm{I}_{1} \mathrm{E}_{2}$ & 8696 & 23825 & 14873 & 3.00 \\
$\mathrm{I}_{1} \mathrm{E}_{3}$ & 8868 & 15040 & 6344 & 1.71 \\
$\mathrm{I}_{2} \mathrm{E}_{1}$ & 7994 & 33150 & 24282 & 5.56 \\
$\mathrm{I}_{2} \mathrm{E}_{2}$ & 7520 & 26325 & 18331 & 5.25 \\
$\mathrm{I}_{2} \mathrm{E}_{3}$ & 17500 & 9980 & 3.81 \\
\hline
\end{tabular}




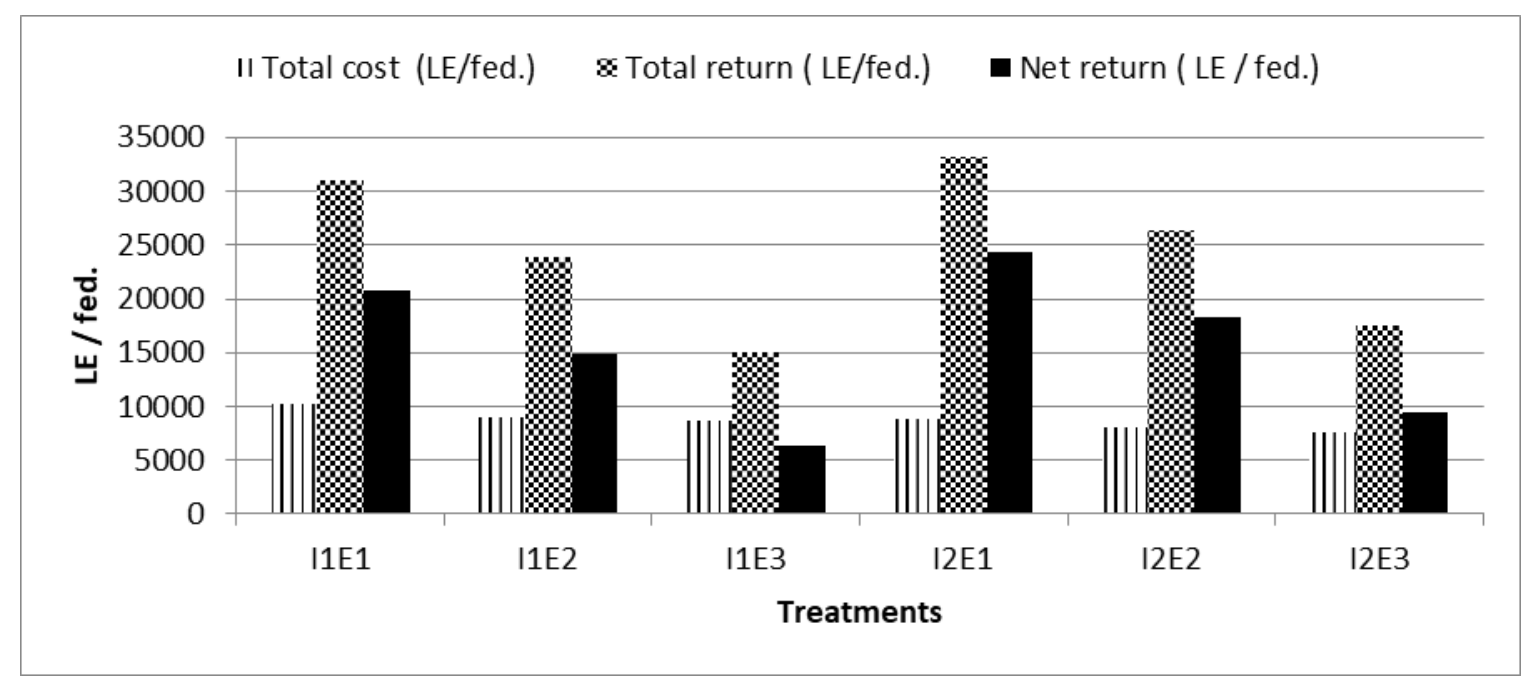

Fig 4. Economic analysis of guava as influenced by irrigation systems and water regime during the growing season 2017 / 2018

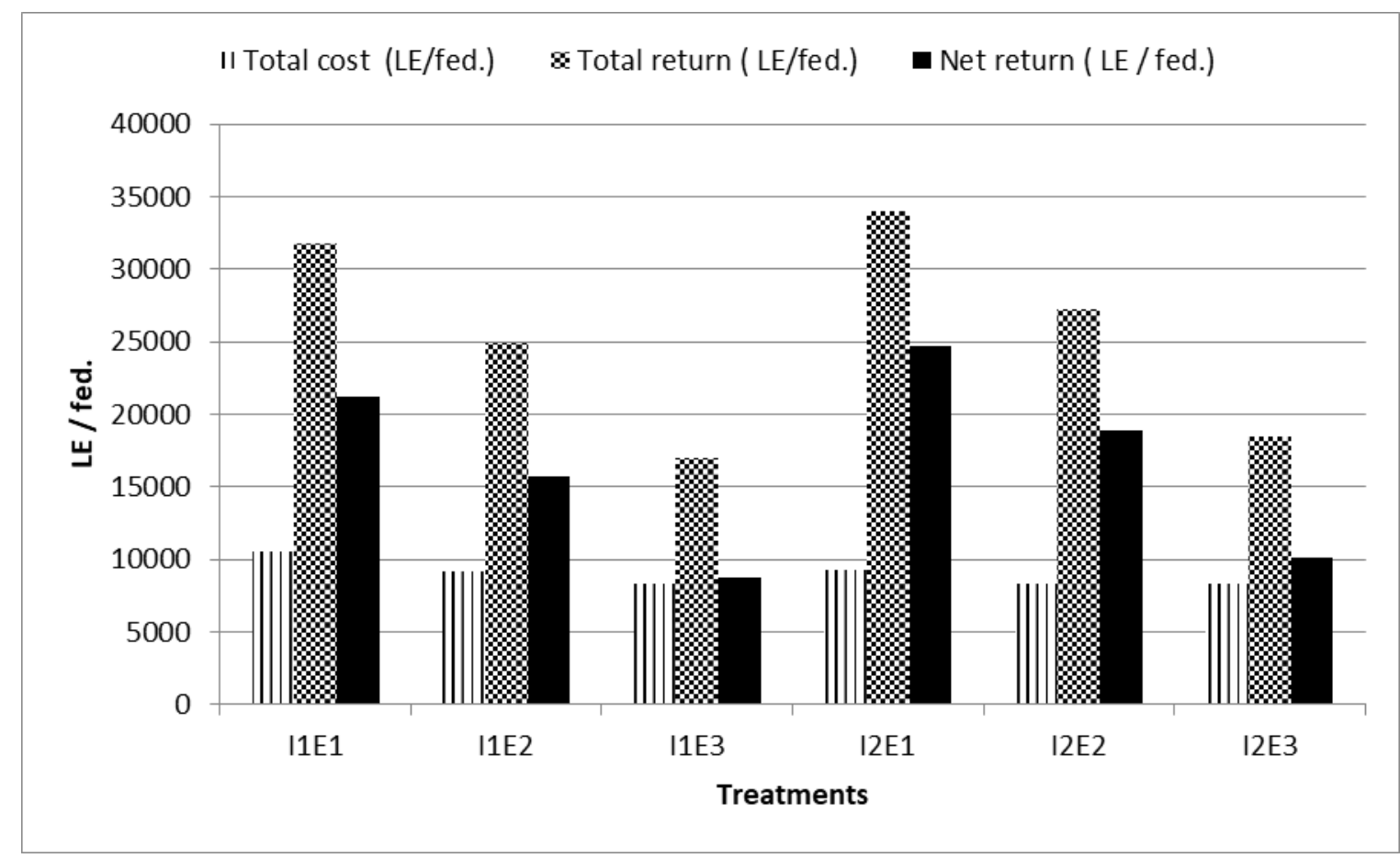

Fig 5. Economic analysis of guava as influenced by irrigation systems and water regime during the growing season 2018 / 2019.

The maximum value of total return was recorded due to $\mathrm{T}_{2} \mathrm{E}_{1}$ treatment for the two growing seasons and the minimum value of total return was recorded as a result of $\mathrm{I}_{1} \mathrm{E}_{3}$ treatment for the two growing seasons. Net return has the same trend of total return in the two growing seasons. Table 10 showed that water productivity (W.P.) has been affected by both irrigation systems and water regime.

The maximum values of water productivity (W.P.) were 5.16 and $4.95 \mathrm{LE} / \mathrm{m}^{3}$ under $\mathrm{I}_{2} \mathrm{E}_{1}$ and $\mathrm{I}_{2} \mathrm{E}_{2}$, 
respectively in the $1^{\text {st }}$ growing season (2017/2018) and recorded 5.56 and $5.25 \mathrm{LE} / \mathrm{m}^{3}$ under $\mathrm{I}_{2} \mathrm{E}_{1}$ and $\mathrm{I}_{2} \mathrm{E}_{2}$, respectively in the $2^{\text {nd }}$ growing season $(2018 / 2019)$. The lowest water productivity was obtained under $\mathrm{T}_{1} \mathrm{E}_{3}$ treatment, which recorded 2.23 and $1.71 \mathrm{LE} / \mathrm{m}^{3}$, respectively for the two growing season : 2017/2018 and 2018/2019.

\section{CONCLUSION}

The results obtained in this study indicated that surface drip irrigation with $100 \% \mathrm{ET}_{\mathrm{c}}$ and $80 \%$ of $\mathrm{ET}_{\mathrm{c}}$ produced higher yield and yield components of guava trees. The highest values of shoot length, number of leaves $/ \mathrm{m}$ and leaf area were obtained as a result of $\mathrm{I}_{2} \mathrm{E}_{1}$ treatment $\left(\mathrm{SDI}\left(\mathrm{I}_{2}\right)+100 \% \mathrm{ET}_{\mathrm{c}}\right)$ while the lowest values were due to $\mathrm{I}_{1} \mathrm{E}_{3}$ treatment (furrow irrigation and $60 \%$ $\mathrm{ET}_{\mathrm{c}}$ ). The highest values of WUE and water productivity (W.P.) were obtained by $\mathrm{I}_{2} \mathrm{E}_{1}$ and $\mathrm{I}_{2} \mathrm{E}_{2}$ treatments in the two growing seasons, while the lowest values of WUE and water productivity (W.P.) were obtained by $\mathrm{I}_{1} \mathrm{E}_{1}$ treatment (furrow irrigation and $100 \%$ $\mathrm{ET}_{\mathrm{c}}$ ). It is clear, therefore, that $\mathrm{I}_{2} \mathrm{E}_{1}$ (drip irrigation with $100 \% \mathrm{ET}_{\mathrm{c}}$ ) and $\mathrm{I}_{2} \mathrm{E}_{2}$ (drip irrigation with $80 \% \quad \mathrm{ET}_{\mathrm{c}}$ ) treatments can be considered the most effective irrigation method with water regime application in improving WUE and increasing yield, yield components and water productivity of guava trees.

It is recommended through the results of this research to replace surface irrigation with drip irrigation with water regime $100 \%$ or $80 \%$. Also, future study should be carried out to evaluate the effect of drip irrigation on clay soil, other plants and its impact on the environments.

\section{REFERENCE}

A.O.A.C. 1975. Association of Official Agricultural Chemists. "Official Methods of Analysis". 12th Ed., Published by AOAC, Washington D.C.,USA.

A.O.A.C. 1995. "Official Methods of Analysis". 16th Ed., Association of Official Analytical Chemists. International, Virginia, USA

Abbas, F.A. and N.A.Anton . 1999. Effect of irrigation intervals on sunflower production $.3^{\text {rd }}$ Conf. of On Farm Irrigation and Agro climatology Vol.(1):pp.633-646, January 25-27 ,1999,Egypt.

Abdel-Mawgowd, A.M., M.A. El-Nemr, A.S. Tantawy, and H.A. Habib.2010. Alleviation of salinity effects on green bean plants using some environmental friendly materials. J. Appl. Sci. Res. 6: 871-878.

Agrawal, N.and S. Agrawal .2007. Effect of different levels of drip irrigation on the growth and yield of pomegranate under Chhattisgarh Region. Orissa. J. Hort. 35:38-46.
Alaa, S. A., D.L. Ammar and M. N. Salah .2012. "Water use efficiency of potato (Solanum tuberosum L.) under different irrigation methods and potassium fertilizer rates". Annals of Agricultural Sciences Volume 57, Issue 2, December 2012, Pages 99-103.

Attia, M. M., A. M. Osman,M.A. Sayed and A.A. El Kafory 1994.Effect of irrigation interval and plant density on sunflower yield in calcareous soil of West Nubaria region. J. Agric. Sci., Mansoura

Univ., 19 (10): 3163-3168.

Badr, M.A., S.D. Abou Hussein, W.A. El-Tohamy and N. Gruda.2010. Efficiency of subsurface drip irrigation for potato production under different dry stress conditions. Gesunde Pflanzen . 62: 63-70.

Bharambe, P.R., M.S. Mungal, D.K. Shelke, S.R. Oza, V.G. Vaishnava and V.D. Sondge .2001. Effect of soil moisture regimes with drip on spatial distribution of moisture, salts, nutrient availability and water use efficiency of banana. J. Ind. Soc. Soil Sci. 49:658-665.

Bisbis, M.B., N. Gruda and M. Blanke .2018. Potential impacts of climate change on vegetable production and product quality -A review. J. Clean. Prod. 170: 16021620.

Biswas, R.K., S.K. Rana, and S. Mallick. 1999. Performance of drip irrigation in papaya cultivation in new alluvium agro-climatic zone of West Bengal. Annals of Agri. Res., 20(1): 116-117.

Black C. A. (ed.). 1965. Method of Soil Analysis, Part 2, Chemical and Microbiological Properties, American Society of Agronomy, Inc, Publisher, Madison, Wisconsin USA.

Boora, R.S., D. Singh, S. Siddiqui and S.L. Verma .2002. Response of sapota to NPK fertilization. Haryana. J. Hort. Sci. 31:15-17.

Doorenbos, J. and W.O.Pruitt .1984. Guidelines for Predicting Crop Water Requirements. Irrigation and Drainage , Paper 24 FAO of UN, Rome, Italy.7.

Darwish, K.H., M. Safaa, A. Momou and S.A. Saleh .2013. Egypt: Land degradation issues with special reference to the impact of climate change. In Combating Desertification in Asia, Africa and Middle East, Proven Practices; Heshmati G.A. and V.R. Squires .2013. Eds.; Springer: Dordrecht, The Netherlands, Chapter 6. pp. 113-136.

Ekren, S., C. Sonmez, E. Ozcakal, Y.S.K. Kurttas, E. Bayram and H.Gurgulu . 2012. The effect of different irrigation water levels onyield and quality characteristics of purple basil (Ocimum basilicumL.). Agric. Water Manage. 109: 155-161.

El-Dakroury, MAE. 2008. "Influence of different irrigation systems and treatments on productivity and fruit quality of some bean varieties". M.Sc. Thesis, Faculty of Agriculture, Tanta University, Egypt: 94.

FAO. 1998. Crop evapotranspiration, guidelines for computing crop water requirements. FAO Irrigation and Drainage Paper No. 56. FAO. Rome. 
Farooq, M., A.Wahid, N. Kobayashi, D.Fujita and S.M.A. Basra .2009. "Plant drought stress: effects, mechanisms and management". Sustainable Agriculture Springer, Netherlands, 29 (1):185-212.

Gad El-Rab, G.M. , N.G.Ainer and Mahmoud S.A. 1993 Effect of drought conditions at different growth periods on sunflower yield and water use.J.Agric.Sci.,Mansoura Univ., 19 (10): 3163-3168.

Horwitz W. 1970 . Official methods of Analysis. Association of Official Analytical Chemists, 11th Ed., Washington D.C., USA.

Ibrahim ,El.G. 2003. Productivity, water use and yield efficiency of banana under different irrigation systems and water quality in sandy soil . Egypt .J. Appl .Sci. 18(10):334-348.

Israelsen ,O.W. and V.E. Hansen .1962. Irrigation principles and practices . $3^{\text {rd }}$ Edit. John Wiley and Sons . Inc. New York.

Khattab ,M. M., A. E.Shaban, A. H. El-Shrief and M. A. S. ElDeen .2011. Growth and productivity of pomegranate trees under different irrigation levels. II: fruit quality. J. Hortic. Sci.

Ornam. Plants. 3(3): 259-264.

Kliewer, W. M. 1977. Effect of high temperature during the bloom-set period on fruit-set, ovule fertility, and berry growth of several grape cultivars. American Journal of Enology and Viticulture 28:215-221.

Kliewer, W. M. and H. B. Schultz .1973. Effect of sprinkler cooling of grapevines on fruit growth and composition. Am. J. Enology Viticulture 24:17-26.

Kliewer ,W. M. 1971. Effect of temperature on the composition of cabernet sauvignon berries. Am. J. Enology Viticulture 22:71-75.

Kumar, A., H. K. Singh, N. Kumari, and P. Kumar. 2009. Effect of fertigation on banana biometric characteristics and fertilizer use efficiency. Agri. Engineering, ISAE. 46(1): 27-31.

Lawand, B.T. and V.k. Patil .1992.Effect of different water regimes on fruit quality of pomegranate (Punica granatum L.). Acta Hortic.. 321: 677-683

Leilah A.A. 2009. "Physiological response of onion to water stress and bio fertilizers". M.Sc. Thesis, Faculty of Agriculture, Mansoura University, Egypt: 121.

Michael A.M. 1978. Irrigation theory and practice. Vikas Publishing House PVTLTD New Delhi, Bombay.
Mutava, R., S. Prince., N. Syed, L. Song, B.Valliodan, W. Chen and H. Nguyen.2015. "Understanding abiotic stress tolerance mechanisms in soybean: A comparative evaluation of soybean response to drought and flooding stress". Plant Physiol and Biochem 86: 109-120.

Ouda, S. 2016. Major Crops and Water Scarcity in Egypt: Irrigation Water Management under Changing Climate; Springer: Cham, Switzerland; ISBN 978-3-319-21771-0.

Page, A. L., R. H. Miller and D. R. KeEney, (Ed., 1982) Methods of Soil Analysis. Part 2. American Society of Agronomy, Madison, Wisconsin, USA.

Patil ,P.V. and V.K. Patil .1999. Influence of different soil water regimes on root distribution in guava. J. Maharashtra. Agric. Univ. 24:45-47.

Pouget, R. 1981. Action de la temperature sur la differenciaction des inflorescences et dus fleurs durant les phases de pre debourrement et de post debourrement des bourgeons latents de la Vigne. Conn. Vigne Vin 15:6579.

Saleh, S.A., Z.S. El-Shal, Z.S. Fawzy and A.M. El-Bassiony .2012. Effect of water amounts on artichoke productivity irrigated with brackish water. Aust. J. Basic Appl. Sci. 6: 54-61.

Salvin, S., K. Baruah and S.K. Bordoloi .2000. Drip irrigation studies in banana cv. Barjahaji (Musa AAA group, Cavendish sub-group). Crop Res. 20:489-493.

SAS Institute, 1996. SAS/stat user's Guide version 6.4th ed SAS Institute Inc. Cary, NC, USA.

Singh, H.K., A.K.P. Singh and A.K. Sinha .2005. Effect of fertigation on fruit growth and yield of papaya with drip irrigation. Haryana. J. Hort. Sci. 34:7-8.

Singh H.P. 2005. Micro irrigation for sustainable agriculture. National Conference on Micro irrigation held at GBPUA\&T, Pantnagar, India. 3-5 June 2005.

Stanhill G. 1986. Water use efficiency. Adv. Agron. 39: 53-85.

Vites, Jr., F.G. 1962. Fertilizers and the efficient use of water. Adv. Agron. 14: 223-264.

Vomocil J.A. 1957. Measurements of soil bulk density and penetrability . A review of method Adv. Agron. 9: 159176.

Wide, S., R. B. Corey, J. G. Lyer and G.Vioget.1985. Soil and Plant Analysis for Tree Culture, 3rd Ed., Oxford, IBH Publishing Co., New Delhi, pp. 93-116.

Zhang, C. and Z. Huang. 2013. "Effects of endogenous abscisic acid, jasmonic acid, polyamines, and polyamine oxidase activity in tomato seedlings under drought stress". Scientia Hort. 159: 172-177. 


\section{الملخص العربي}

تاثير نظم الرى والرجيم المائى على كلا من النمو ومكونات المحصول وكفاءة إستخدام الماء والانتاجية المائية للجوافة المنزرعة فى التربة الطينية

أشرف السيد النماس

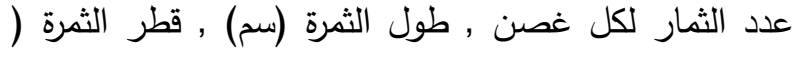
سم) , حجم الثرة (سم3) والمحصول ( كجم/شجرة). كانت كفاءة إستخدام المياة لمعاملات الرى بالتتقيط أعلى عند مقارنتها لمعاملات الرى السطحى بالخطوط خلام موسمى النمو • حيث ذادت قيم كفاءة استخدام المياه من 2.37 و 3.34 كجم/23 تحت معاملة الرى بالتتقيط بينما تراوحت بين 1.63 و 2.18 كجم/23 فى معاملة الرى بالخطوط خلال موسمى النمو (2017 /2018) و (2018 /2019) على (2018) الترتيب. كما أوضحت النتائج عدم وجود فروق معنوية للخواص الكيميائية لثمار محصول الجوافة والتى تشتمل على المكونات الصلبة الكلية والحموضة وانسبة بين الصلبة الكلية والحموضة. وكان أقصى صافى عائد ( 24411 جنية/ فدان ) خلال موسمى النمو (2017 /2018) و (2018 /2019 ) تم تسجيله عند تطبيق معاملة الرى بالتتقيط و100 النو بخر نتح المحصولى بينما أقل صافى عائد ( 6344 جنية / فدان ) تم تسجيلة عند تطبيق معاملة الرى السطحى بالخطوطو 60 \% بخر نتح - محصولى .تم التحصل على أقصى إنتاجية للماء (5.56 جنية / م 3 , 5.25 جنية / م 3 ) عند تطبيق نظام الرى بالتتقيط ورجيم مائى 100 و 80

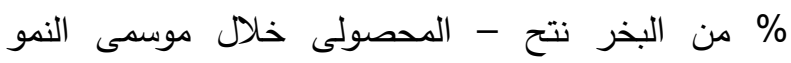
(2018/2017 ) و (2018 /2019 ) ) على الترتيب.
أجريت تجارب حقلية خلال موسمين زراعيين متتاليين (2018/2017) و (2019) (2018) فى بستان للجوافة بمدينة كفر الدوار , محافظة البحيرة , جمهورية مصر العربية

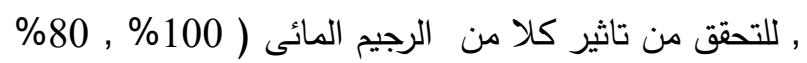
, 60 \% من البخرنتح المحصولى) و نظامى رى (الرى من ليرى

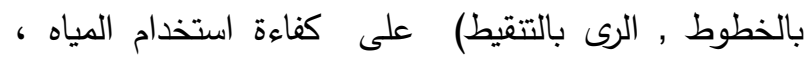

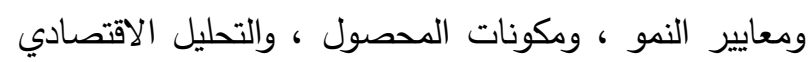

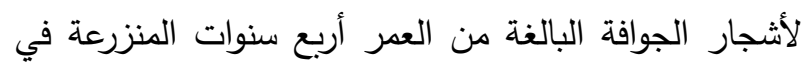
التربة الطينية .تم تتفيذ التجربة في تصميم القطاعات العشوائية الكاملة بثلاثة مكررات.وقد بينت النتائج المتحصل عليها أن الرى بالتتقيط السطحى مع رجيم مائى 100 , 80

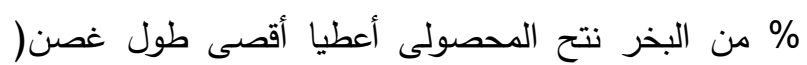
فسيلة) , عدد الأوراق لكل غصن وكذلك مساحة الاوراق (سم 2) . كان أقصى محصول جوافة عند تطبيق معاملة الرى الرى بالتتقيط و 100 \% بخر نتح- محصولى حيث سجلت هذة المعاملة 11.33 و 11.05 طن / فدان خلال موسمى النمو (2018/2017 ) و(2018) و (2018) على الترتيب بينما أقل محصول عند تطبيق معاملة الرى السطحى بالخطوط و 60 \% بخر نتح - محصولى حيث سجلت هذة المعاملة 8.50 و 7.52 طن / فدان خلال موسمى النمو (2017 /2018) و (2018 /2019) على الترتيب • كما وجد إختلافات معنوية بين مكونات المحصول والتى تشتمل على 